\title{
SB5 with the Estimated Impact of Low-Temperature Aluminum Dissolution: Preliminary Frits for Melt Rate Testing
}

K. M. Fox

T. B. Edwards

March 2008

Process Science and Engineering Savannah River National Laboratory Aiken, SC 29808

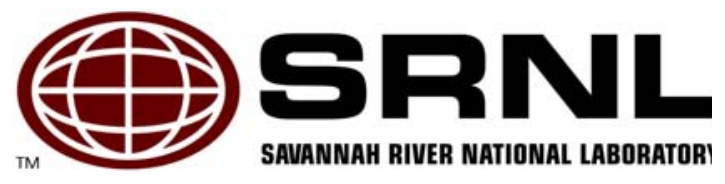


WSRC-STI-2008-00006

Revision 0

\section{DISCLAIMER}

This report was prepared by Washington Savannah River Company (WSRC) for the United States Department of Energy under Contract No. DE-AC09-96SR18500 and is an account of work performed under that contract. Neither the United States Department of Energy, nor WSRC, nor any of their employees makes any warranty, expressed or implied, or assumes any legal liability or responsibility for the accuracy, completeness, or usefulness, of any information, apparatus, or product or process disclosed herein or represents that its use will not infringe privately owned rights. Reference herein to any specific commercial product, process, or service by trademark, name, manufacturer or otherwise does not necessarily constitute or imply endorsement, recommendation, or favoring of same by WSRC or by the United States Government or any agency thereof. The views and opinions of the authors expressed herein do not necessarily state or reflect those of the United States Government or any agency thereof.

\section{Printed in the United States of America \\ Prepared For \\ U.S. Department of Energy}

The Savannah River National Laboratory is operated for the U.S. Department of Energy by Washington Savannah River Company. 
Keywords: sludge mass

reduction, glass formulation, waste loading

Retention: permanent

\section{SB5 with the Estimated Impact of Low-Temperature Aluminum Dissolution: Preliminary Frits for Melt Rate Testing}

K. M. Fox

T. B. Edwards

March 2008

Process Science and Engineering Savannah River National Laboratory Aiken, SC 29808 


\section{REVIEWS AND APPROVALS}

\section{AUTHORS:}

K.M. Fox, Process Science and Engineering Section

Date

T.B. Edwards, Statistical Consulting Section

Date

\section{TECHNICAL REVIEWER:}

D.K. Peeler, Process Science and Engineering Section

Date

\section{APPROVERS:}

D.A. Crowley, Manager, Stabilization Science Research

Date

C.C. Herman, Manager, Process Engineering Technology Group

Date

J.C. Griffin, Manager,

Date

Environmental \& Chemical Process Technology Research Programs

J.E. Occhipinti, Manager, Process Cognizant Engineering

Date

Waste Solidification Engineering 
WSRC-STI-2008-00006

Revision 0

\section{EXECUTIVE SUMMARY}

Composition projections for Sludge Batch 5 (SB5) were developed to evaluate possible impacts of the Al-dissolution process on the availability of viable frit compositions for vitrification at the DWPF. The study included two projected SB5 compositions that bound potential outcomes (or degrees of effectiveness) of the Al-dissolution process, as well as a nominal SB5 composition projection based on the results of the recent Al-dissolution demonstration at SRNL. A Nominal Stage assessment was used to evaluate the two SB5 projections combined with an array of 19,305 frit compositions over a range of waste loading (WL) values against the DWPF process control models. The Nominal Stage results allowed for the down-selection of a small number of frits that provided reasonable projected operating windows (typically 25 to $40 \mathrm{wt} \%$ ) and permitted some compositional flexibility (i.e., the ability to further tailor the frit to improve melt rate).

Variation Stage assessments were then performed using the down-selected frits and the two SB5 composition projections with variation applied to each sludge component. The Variation Stage results showed that the operating windows were somewhat reduced in width, as expected when sludge variation is applied. Three of the down-selected frits continued to perform well for both SB5 projections through the Variation Stage, providing WL windows of approximately 26 to 35 wt \%. The maximum WLs were limited by a processing constraint, $\mathrm{T}_{\mathrm{L}}$, rather than a waste form affecting constraint (e.g., nepheline crystallization) in the Variation Stage assessments.

Subsequent Nominal Stage assessments were performed with an updated SB5 projection based on the results of the Al-dissolution demonstration performed in the SRNL Shielded Cells facility (representing 40\% removal of $\mathrm{Al}$ ). The three frits identified in the earlier paper studies continued to perform well with this updated projection. The available operating windows were slightly wider, although maximum WL was limited by both the $T_{L}$ and nepheline constraints for all three frits.

Changes in the projected SB5 composition are anticipated before processing begins at the DWPF, which will likely require additional paper study assessments as well as experimental frit development studies. This study identifies several frits which provide insight into potential operating windows for SB5 vitrification in DWPF. However, until experimental studies can be performed to gain information on melt rate and other parameters needed to optimize frit selection, no final frit recommendation can be made.

Information regarding melt rate cannot be inferred from the paper study results. Experimental studies to evaluate this critical factor in DWPF processing must be performed to support frit optimization for any projected sludge composition. Five frit compositions were identified for melt rate testing at SRNL with simulated SB5 Case F SRAT product. The results of these tests will be used to evaluate the impact of the frit components - particularly $\mathrm{B}_{2} \mathrm{O}_{3}$ and $\mathrm{Na}_{2} \mathrm{O}$ - that are expected to influence melt rate for SB5-like sludges. The results of the melt rate testing will be documented in a separate report and will be used to help guide the frit recommendation process as the final SB5 composition becomes clearer. 


\section{TABLE OF CONTENTS}

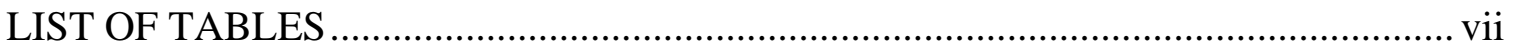

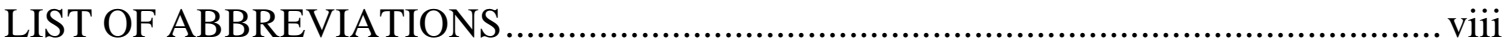

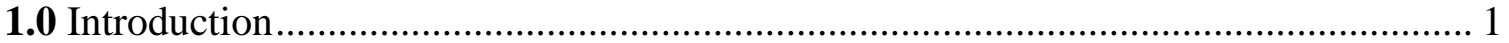

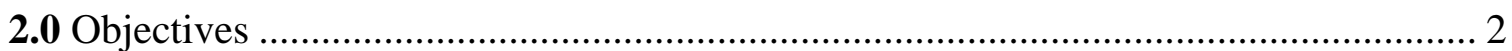

3.0 Sludge Batch 5 Composition Projections ............................................................... 2

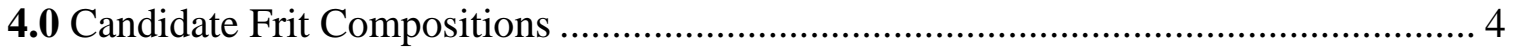

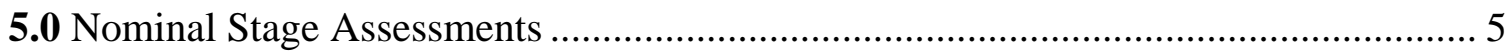

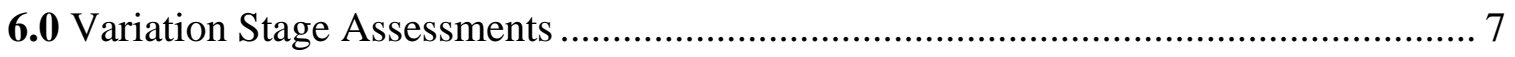

7.0 Additional Nominal Stage Assessments at 40\% Aluminum Removal ........................ 8

8.0 Frit Selection for Experimental Melt Rate Studies ................................................... 9

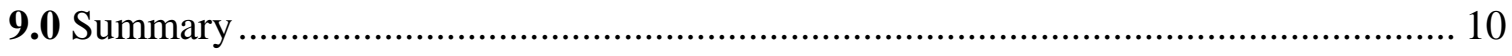

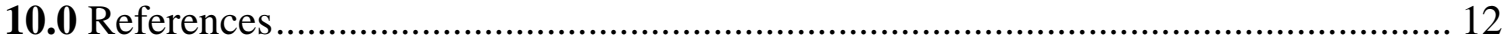

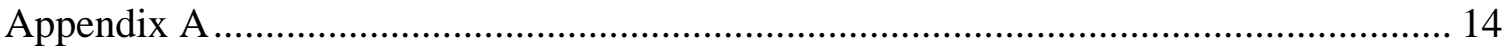




\section{LIST OF TABLES}

Table 3-1. SB5 composition projections as a function of Gibbsite/Boehmite partitioning............ 3

Table 3-2. Updated SB5 composition projection (SB5 Case F) based on 40\% dissolution of aluminum. Cases B and $\mathrm{C}$ are included for comparison................................................... 4

Table 4-1. Frit components and concentration ranges used to define the frit composition array for MAR assessments.

Table 5-1. Candidate frits for SB5 down-selected from the Nominal Stage results....................... 5

Table 5-2. Summary of Nominal Stage results for SB5 Case B with the candidate frits............... 6

Table 5-3. Summary of Nominal Stage results for SB5 Case C with the candidate frits............... 6

Table 6-1. Compositions of SB5 Cases B and C with variation applied...................................... 7

Table 6-2. Summary of Variation Stage results for SB5 Case B with the candidate frits.............. 8

Table 6-3. Summary of Variation Stage results for SB5 Case C with the candidate frits.............. 8

Table 7-1. Summary of Nominal Stage results for SB5 Case F with the candidate frits. .............. 9 


\section{LIST OF ABBREVIATIONS}

$\begin{array}{ll}\text { ARP } & \text { Actinide Removal Process } \\ \text { CPC } & \text { Chemical Process Cell } \\ \text { DOE } & \text { Department Of Energy } \\ \text { DWPF } & \text { Defense Waste Processing Facility } \\ \text { EVs } & \text { Extreme Vertices } \\ \text { highv } & \text { high viscosity } \\ \text { homg } & \text { homogeneity } \\ \text { lowv } & \text { low viscosity } \\ \text { LWO } & \text { Liquid Waste Organization } \\ \text { MAR } & \text { Measurement Acceptability Region } \\ \text { MRF } & \text { Melt Rate Furnace } \\ \text { Neph } & \text { Nepheline crystallization } \\ \text { NL } & \text { Normalized Leachate } \\ \text { PCCS } & \text { Product Composition Control System } \\ \text { SB4 } & \text { Sludge Batch 4 } \\ \text { SB5 } & \text { Sludge Batch 5 } \\ \text { SRAT } & \text { Sludge Receipt and Adjustment Tank } \\ \text { SRS } & \text { Savannah River Site } \\ \text { T }_{\mathrm{L}} & \text { liquidus temperature } \\ \text { WL } & \text { Waste Loading }\end{array}$


WSRC-STI-2008-00006

Revision 0

\subsection{Introduction}

The current contents of Tank 51 will be blended with Purex sludge from Tank 7 to constitute Sludge Batch 5 (SB5). The Savannah River Site (SRS) Liquid Waste Organization (LWO) is performing low-temperature Al-dissolution in Tank 51 to reduce the total mass of sludge solids and $\mathrm{Al}$ being fed to the Defense Waste Processing Facility (DWPF). A radioactive demonstration using a $3 \mathrm{~L}$ Tank 51 sludge slurry sample was performed to verify the Tank Farm processing parameters. ${ }^{1}$ The aluminum dissolved sludge was used to determine potential downstream impacts so that technical issues could be identified before the start of SB5 processing. The potential downstream impacts assessed included the Tank Farm washing and concentration process and the DWPF Chemical Process Cell (CPC) and melter processing envelopes.

This report focuses on the impacts to the development of a glass frit to be combined with the reduced $\mathrm{Al}$ concentration sludge for vitrification in the DWPF melter. An assessment is made of the impact of Al-dissolution on the DWPF projected operating windows as defined by the current process control models. The evaluation includes two projected SB5 compositions that bound potential outcomes (or degrees of effectiveness) of the Al-dissolution process, as well as a nominal SB5 composition projection based on the outcome of the recent Al-dissolution demonstration at SRNL. ${ }^{\text {a }}$ Paper study assessments of the compositional projections are used to assess various frit/sludge options of interest with respect to the projected operating windows (as defined by a waste loading interval) for DWPF. More specifically, for each sludge option, the current Product Composition Control System (PCCS) models were used to assess the waste loading interval over which glasses would concurrently meet all process and acceptability constraints. Candidate frits are identified that provide a reasonable projected operational window over the anticipated composition region of interest and are robust to anticipated sludge composition variations.

The two stages - Nominal Stage and Variation Stage - traditionally performed by Peeler and Edwards ${ }^{2}$ were employed to assess the various frit/sludge combinations with respect to these key criteria. The Nominal Stage utilizes nominal compositions representing the potential scenarios outlined above (i.e., various amounts of alumina removed from the sludge). This stage identified candidate frit compositions with respect to their ability to provide a reasonable operating window based solely on a specific nominal composition - no sludge composition variation was considered in this phase.

The Variation Stage assessment was performed to gain insight into the robustness of the candidate frits with respect to potential composition variation resulting from uncertainties in Tank Farm blending strategies or volumes. A down-select process was used to identify primary frit candidates from the Nominal Stage results prior to performing the Variation Stage assessment.

The paper study assessments do not provide specific guidance regarding melt rate differences among the various SB5 flowsheets or frit compositions. The assessments are based strictly on model predictions and the projected operating windows over which all glass properties are deemed acceptable based on current DWPF acceptance criteria. Experimental studies will be necessary to provide melt rate information and guide further decisions on frit compositions for processing SB5 at the DWPF. A select set of frit compositions is identified in this report for this purpose. These frits will be used to determine how general trends in frit composition, such as the concentrations of $\mathrm{B}_{2} \mathrm{O}_{3}$ and $\mathrm{Na}_{2} \mathrm{O}$, impact melt rate for SB5-like systems.

\footnotetext{
${ }^{a}$ Note that these projections do not include the addition of waste streams from the Actinide Removal Process (ARP).
} 
WSRC-STI-2008-00006

Revision 0

This work was performed in response to Technical Task Request HLW-DWPF-TTR-2007-0007 and was carried out following Task Technical and Quality Assurance Plan WSRC-STI-200600321. ${ }^{3,4}$

\subsection{Objectives}

The intent of this study is to ensure that candidate frits can be identified for use with SB5 that:

- provide reasonable operating windows in terms of percent waste loading (WL), and

- provide sufficient opportunity to vary the concentration of frit components, particularly $\mathrm{B}_{2} \mathrm{O}_{3}$ and $\mathrm{Na}_{2} \mathrm{O}$, and to assess their impact on melt rate.

This preliminary selection of candidate frits and the subsequent melt rate testing results will allow for the identification of frit compositional trends in melt rate for SB5-like systems. These trends will be used to support the frit recommendation process given that current schedules will provide little time for additional melt rate testing after receipt of the final SB5 composition and prior to the need for a frit recommendation. ${ }^{\mathrm{a}}$

\subsection{Sludge Batch 5 Composition Projections}

SRNL used a modeling approach to project the anticipated composition of SB5 in support of this study. A detailed description of the modeling methodology is provided in WSRC-STI-200800001. ${ }^{5}$ The model required the following input vectors, which were constructed from available analytical data:

- Tank 51 slurry prior to dilution with Tank 40 supernate $^{6}$

- Tank 40 supernate ${ }^{b}$

- Tank 7 slurry $^{7}$

- Information on various water leaks, miscellaneous additions, missing ion chromatography data, etc. ${ }^{\mathrm{c}}$

Five composition projection cases were developed for SB5 at the initiation of this study. The five cases project the potential outcomes of the low-temperature $\mathrm{Al}$-dissolution process based on the partitioning of $\mathrm{Al}$ between Gibbsite and Boehmite in Tank 51. The amount of Al partitioning to Gibbsite was varied between $0 \%$ and $100 \%$ in increments of $25 \%$. The projections are based on the assumption that a blend of approximately $80 \%$ material from Tank 51 and 20\% material from Tank 40 constitute the SB5 feed to DWPF (i.e., a 40 inch heel remaining in Tank 40 when the blend occurs). ${ }^{\mathrm{d}}$ These composition projections for SB5 - the output of the SRNL model as elemental values - are given in Table 3-1. The projections are listed as a function of Gibbsite/Boehmite partitioning.

\footnotetext{
${ }^{a}$ Recognizing that the frits selected in this report are for sludge-only systems (i.e., without the addition of ARP), it is assumed that the trends ascertained from the melt rate studies can be used to support frit selection for coupled and/or sludge-only flowsheets as warranted.

${ }^{\mathrm{b}}$ Analytical Laboratories report 23Apr07 09:31 Hr

c Tank Farm Spreadsheet 19Jun07

${ }^{\mathrm{d}}$ This assumption has a significant impact on the projected compositions. The final blend composition will ultimately be determined by the amount of aluminum removed from Tank 51, the amount of SB4 remaining in Tank 40, any decants that are made from Tank 40 prior to the blend, and any other changes in the LWO washing and/or blending strategy.
} 
Table 3-1. SB5 composition projections as a function of Gibbsite/Boehmite partitioning.

\begin{tabular}{|c|c|c|c|c|c|}
\hline SB5 Case & $\overline{\mathbf{A}}$ & $\overline{\mathbf{B}}$ & 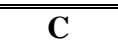 & 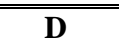 & $\bar{E}$ \\
\hline Gibbsite (\%) & 0 & 25 & 50 & 75 & 100 \\
\hline Boehmite (\%) & 100 & 75 & 50 & 25 & 0 \\
\hline $\mathrm{Ag}$ & 0.008 & 0.009 & 0.010 & 0.011 & 0.011 \\
\hline $\mathrm{Al}$ & 17.063 & 15.326 & 13.167 & 11.062 & 10.140 \\
\hline $\mathrm{Ba}$ & 0.083 & 0.091 & 0.101 & 0.108 & 0.110 \\
\hline $\mathrm{Ca}$ & 1.163 & 1.273 & 1.404 & 1.505 & 1.539 \\
\hline $\mathrm{Cd}$ & 0.049 & 0.053 & 0.058 & 0.063 & 0.065 \\
\hline $\mathrm{Ce}$ & 0.289 & 0.316 & 0.349 & 0.374 & 0.383 \\
\hline $\mathrm{Co}$ & 0.017 & 0.019 & 0.020 & 0.022 & 0.022 \\
\hline $\mathrm{Cr}$ & 0.233 & 0.255 & 0.281 & 0.301 & 0.307 \\
\hline $\mathrm{Cu}$ & 0.010 & 0.010 & 0.010 & 0.010 & 0.011 \\
\hline $\mathrm{Fe}$ & 14.855 & 16.251 & 17.926 & 19.216 & 19.646 \\
\hline $\mathrm{K}$ & 0.052 & 0.055 & 0.059 & 0.066 & 0.069 \\
\hline $\mathrm{La}$ & 0.127 & 0.139 & 0.153 & 0.164 & 0.168 \\
\hline $\mathrm{Mg}$ & 0.649 & 0.710 & 0.783 & 0.839 & 0.858 \\
\hline $\mathrm{Mn}$ & 3.439 & 3.763 & 4.150 & 4.449 & 4.549 \\
\hline $\mathrm{Na}$ & 18.877 & 18.413 & 17.938 & 18.164 & 18.545 \\
\hline $\mathrm{Ni}$ & 1.960 & 2.144 & 2.365 & 2.535 & 2.592 \\
\hline $\mathrm{P}$ & 0.211 & 0.230 & 0.253 & 0.271 & 0.277 \\
\hline $\mathrm{Pb}$ & 0.019 & 0.020 & 0.022 & 0.024 & 0.025 \\
\hline Pd & 0.001 & 0.001 & 0.001 & 0.001 & 0.001 \\
\hline $\mathrm{Rh}$ & 0.024 & 0.026 & 0.029 & 0.031 & 0.032 \\
\hline $\mathrm{Ru}$ & 0.091 & 0.099 & 0.109 & 0.117 & 0.120 \\
\hline $\mathrm{S}$ & 0.235 & 0.243 & 0.254 & 0.272 & 0.281 \\
\hline $\mathrm{Si}$ & 0.818 & 0.881 & 0.972 & 1.044 & 1.067 \\
\hline $\mathrm{Sr}$ & 0.246 & 0.269 & 0.297 & 0.318 & 0.325 \\
\hline $\mathrm{Ti}$ & 0.014 & 0.015 & 0.017 & 0.018 & 0.019 \\
\hline $\mathrm{U}$ & 5.761 & 6.303 & 6.952 & 7.453 & 7.619 \\
\hline $\mathrm{Zn}$ & 0.012 & 0.013 & 0.013 & 0.015 & 0.015 \\
\hline $\mathrm{Zr}$ & 0.175 & 0.191 & 0.211 & 0.226 & 0.231 \\
\hline Total (wt \%) & 66.483 & 67.120 & 67.906 & 68.681 & 69.026 \\
\hline Tk51 Transfer (kg) & 238,491 & 200,032 & 173,315 & 161,004 & 160,709 \\
\hline Tk40 Heel (kg) & 37,733 & 37,733 & 37,733 & 37,733 & 37,733 \\
\hline Tk51 Solids (\%) & 86 & 84 & 82 & 81 & 81 \\
\hline Tk40 Solids (\%) & 14 & 16 & 18 & 19 & 19 \\
\hline
\end{tabular}

During the course of this study, the results of the 3L demonstration in the SRNL Shielded Cells facility showed that approximately $35 \%$ of the $\mathrm{Al}$ was removed after dissolution and washing. ${ }^{1}$ This suggested that the SB5 composition would fall between Case B (25\% Gibbsite) and Case C (50\% Gibbsite). The data from the Shielded Cells demonstration were used to develop a revised projection, labeled Case F, which is given in Table 3-2. The concentration of each component in Case $\mathrm{F}$ falls between its corresponding concentration in Cases B and C. 
Table 3-2. Updated SB5 composition projection (SB5 Case F) based on $40 \%$ dissolution of aluminum. Cases $B$ and $C$ are included for comparison.

\begin{tabular}{|c|c|c|c|}
\hline SB5 Case & B & $\mathrm{C}$ & $\mathbf{F}$ \\
\hline Gibbsite (\%) & 25 & 50 & 40 \\
\hline Boehmite (\%) & 75 & 50 & 60 \\
\hline $\mathrm{Ag}$ & 0.009 & 0.010 & 0.009 \\
\hline $\mathrm{Al}$ & 15.326 & 13.167 & 14.38 \\
\hline $\mathrm{Ba}$ & 0.091 & 0.101 & 0.096 \\
\hline $\mathrm{Ca}$ & 1.273 & 1.404 & 1.345 \\
\hline $\mathrm{Cd}$ & 0.053 & 0.058 & 0.056 \\
\hline $\mathrm{Ce}$ & 0.316 & 0.349 & 0.331 \\
\hline Co & 0.019 & 0.020 & 0.019 \\
\hline $\mathrm{Cr}$ & 0.255 & 0.281 & 0.266 \\
\hline $\mathrm{Cu}$ & 0.010 & 0.010 & 0.010 \\
\hline $\mathrm{Fe}$ & 16.251 & 17.926 & 17.120 \\
\hline $\mathrm{K}$ & 0.055 & 0.059 & 0.057 \\
\hline $\mathrm{La}$ & 0.139 & 0.153 & 0.145 \\
\hline $\mathrm{Mg}$ & 0.710 & 0.783 & 0.747 \\
\hline $\mathrm{Mn}$ & 3.763 & 4.150 & 3.967 \\
\hline $\mathrm{Na}$ & 18.413 & 17.938 & 17.967 \\
\hline $\mathrm{Ni}$ & 2.144 & 2.365 & 2.249 \\
\hline $\mathrm{P}$ & 0.230 & 0.253 & 0.242 \\
\hline $\mathrm{Pb}$ & 0.020 & 0.022 & 0.021 \\
\hline $\mathrm{Pd}$ & 0.001 & 0.001 & 0.001 \\
\hline $\mathrm{Rh}$ & 0.026 & 0.029 & 0.028 \\
\hline $\mathrm{Ru}$ & 0.099 & 0.109 & 0.104 \\
\hline $\mathrm{S}$ & 0.243 & 0.254 & 0.249 \\
\hline $\mathrm{Si}$ & 0.881 & 0.972 & 0.921 \\
\hline $\mathrm{Sr}$ & 0.269 & 0.297 & 0.286 \\
\hline $\mathrm{Ti}$ & 0.015 & 0.017 & 0.016 \\
\hline $\mathrm{U}$ & 6.303 & 6.952 & 6.612 \\
\hline $\mathrm{Zn}$ & 0.013 & 0.013 & 0.013 \\
\hline $\mathrm{Zr}$ & 0.191 & 0.211 & 0.202 \\
\hline Total (wt \%) & 67.120 & 67.906 & 67.459 \\
\hline Tk51 Transfer (kg) & 200,032 & 173,315 & 268,317 \\
\hline TK40 Heel (kg) & 37,733 & 37,733 & 54,322 \\
\hline Tk51 Solids (\%) & 84 & 82 & 83 \\
\hline Tk40 Solids (\%) & 16 & 18 & 17 \\
\hline
\end{tabular}

\subsection{Candidate Frit Compositions}

An array of frit compositions was developed to be combined with the SB5 composition projections (Cases B, C and F) in the Nominal Stage assessment. The frit components and their concentration ranges were selected based on SRNL experience in previous frit development efforts, ${ }^{8-15}$ DWPF operational constraints, and practicality issues related to frit production. The frit components and their concentrations that define the frit array used are shown in Table 4-1. A total of 19,305 frits were defined using this array. 
WSRC-STI-2008-00006

Revision 0

Table 4-1. Frit components and concentration ranges used to define the frit composition array for MAR assessments.

\begin{tabular}{||c|c|c|c||}
\hline Component & $\begin{array}{c}\text { Min. Concentration } \\
\text { (wt \%) }\end{array}$ & $\begin{array}{c}\text { Max. Concentration } \\
\text { (wt \%) }\end{array}$ & $\begin{array}{c}\text { Increment } \\
\text { (wt \%) }\end{array}$ \\
\hline $\mathrm{B}_{2} \mathrm{O}_{3}$ & 8.0 & 20.0 & 1.0 \\
\hline $\mathrm{CaO}$ & 0.0 & 8.0 & 2.0 \\
\hline $\mathrm{Li}_{2} \mathrm{O}$ & 4.0 & 12.0 & 1.0 \\
\hline $\mathrm{MgO}$ & 0.0 & 4.0 & 2.0 \\
\hline $\mathrm{Na}_{2} \mathrm{O}$ & 2.0 & 12.0 & 1.0 \\
\hline $\mathrm{SiO}_{2}$ & 44.0 & 86.0 & 1.0 \\
\hline
\end{tabular}

\subsection{Nominal Stage Assessments}

Sludge Cases B and C were each combined with the array of frits (19,305 total frit compositions) over a WL interval of 25 to $60 \mathrm{wt} \%$ and evaluated against the models currently implemented in the DWPF to constitute the Nominal Stage assessment. The property predictions assessed included those for liquidus temperature $\left(\mathrm{T}_{\mathrm{L}}\right)$, viscosity $(\eta)$, durability (normalized leachate for boron, NL[B]), homogeneity (homg), high viscosity (highv), low viscosity (lowv), high chromia concentration $\left(\mathrm{Cr}_{2} \mathrm{O}_{3}\right)$, high sulfate concentration $\left(\mathrm{SO}_{4}{ }^{2-}\right)$ and nepheline formation (Neph). ${ }^{\mathrm{a}}$

The Nominal Stage results were evaluated in order to down-select a small number of frits for the Variation Stage and for melt rate testing. Four frit compositions were chosen based on their ability to provide a relatively wide operating window for both SB5 Case B and Case C. These frits will be referred to as Frit 530, Frit 531, Frit 532 and Frit 533. Two additional frits were selected based on the operating windows available individually for Case B (Frit 534) and Case C (Frit 535). An additional factor in the choice of these frits was the range of $\mathrm{B}_{2} \mathrm{O}_{3}$ concentrations (10-16 wt \%) and $\mathrm{Na}_{2} \mathrm{O}$ (4-8 wt \%) concentrations that they represent. These components are known to have a significant impact on melt rate and will be used to identify general trends in melt rate for SB5. The compositions of the down-selected frits are given in Table 5-1.

Table 5-1. Candidate frits for SB5 down-selected from the Nominal Stage results.

\begin{tabular}{||c|c|c|c|c|c|c||}
\hline $\begin{array}{c}\text { Frit } \\
\text { ID }\end{array}$ & $\begin{array}{c}\mathbf{B}_{2} \mathbf{O}_{3} \\
\text { (wt \%) }\end{array}$ & $\begin{array}{c}\mathbf{C a O} \\
\text { (wt \%) }\end{array}$ & $\begin{array}{c}\mathbf{L i}_{2} \mathbf{O} \\
\text { (wt \%) }\end{array}$ & $\begin{array}{c}\mathbf{M g O} \\
\text { (wt \%) }\end{array}$ & $\begin{array}{c}\mathbf{N a}_{2} \mathbf{O} \\
\text { (wt \%) }\end{array}$ & $\begin{array}{c}\mathbf{S i O}_{2} \\
\text { (wt \%) }\end{array}$ \\
\hline 530 & 10.0 & 4.0 & 7.0 & 0.0 & 7.0 & 72.0 \\
\hline 531 & 11.0 & 2.0 & 7.0 & 0.0 & 7.0 & 73.0 \\
\hline 532 & 14.0 & 2.0 & 6.0 & 0.0 & 7.0 & 71.0 \\
\hline 533 & 16.0 & 0.0 & 5.0 & 0.0 & 8.0 & 71.0 \\
\hline 534 & 15.0 & 0.0 & 9.0 & 0.0 & 4.0 & 72.0 \\
\hline 535 & 14.0 & 0.0 & 7.0 & 0.0 & 8.0 & 71.0 \\
\hline
\end{tabular}

\footnotetext{
${ }^{a}$ It should also be noted that a $\mathrm{SO}_{4}{ }^{2-}$ solubility limit of $0.4 \mathrm{wt} \%$ was used in these assessments. It is anticipated that the sulfate limit for the SB5 system will be the same as that for the Sludge Batch 4 (SB4) system: $0.60 \mathrm{wt} \% \mathrm{SO}_{4}{ }^{2-}$ or $0.88 \mathrm{wt} \% \mathrm{Na}_{2} \mathrm{SO}_{4}$ in glass. This should be considered for any frit/sludge systems that may be limited by the $0.4 \mathrm{wt} \%$ $\mathrm{SO}_{4}{ }^{2-}$ constraint. The $\mathrm{SO}_{4}{ }^{2-}$ constraint is not encountered in the discussion of the paper study assessments provided in the main text of this report. However, the data in the appendices show cases where the frit/sludge systems studied were limited by several constraints, including the $\mathrm{SO}_{4}{ }^{2-}$ limit.
} 
A summary of the Nominal Stage assessment for the five candidate frits identified for SB5 Case B is given in Table 5-2. The widths of the available operating windows range from 13 to 16 percentage points in WL. The minimum WL was limited only for Frits 533 and 534 by the homogeneity constraint (at the Property Acceptability Region). ${ }^{a}$ The maximum WL was limited by predictions of nepheline crystallization for all frits, as well as $T_{L}$ for Frit 534 . The $T_{L}$ constraint relates to the DWPF process and does not necessarily affect waste form performance. Nepheline formation can reduce the durability of the glass product and is of greater concern. However, for the purpose of preliminary melt rate testing, it was considered more important to identify frits that covered a wide compositional range while allowing for wide operating windows, rather than focusing on the limiting constraints.

Table 5-2. Summary of Nominal Stage results for SB5 Case B with the candidate frits.

\begin{tabular}{||l|c|c|c|c|c||}
\hline & Frit 530 & Frit 531 & Frit 532 & Frit 533 & Frit 534 \\
\hline $\begin{array}{l}\text { Operating } \\
\text { Window } \\
\text { (\% WL) }\end{array}$ & $25-40$ & $25-40$ & $25-39$ & $27-39$ & $27-42$ \\
\hline $\begin{array}{l}\text { Lower Limiting } \\
\text { Constraint(s) }\end{array}$ & - & - & - & Homg & Homg \\
\hline $\begin{array}{l}\text { Upper Limiting } \\
\text { Constraint(s) }\end{array}$ & Nepheline & Nepheline & Nepheline & Nepheline & $\mathrm{T}_{\mathrm{L}}$, Nepheline \\
\hline
\end{tabular}

A summary of the Nominal Stage assessment for the five candidate frits identified for SB5 Case $\mathrm{C}$ is given in Table 5-3. The widths of the operating windows range from 12 to 16 percentage points in terms of available WLs. The minimum WL was limited by the homogeneity constraint for Frits 533 and 535. The maximum WL was limited by $T_{L}$ predictions for all frits, as well as the nepheline constraint for Frit 535. The shift away from nepheline as a limiting constraint for Case $\mathrm{C}$ is due to the reduced concentrations of $\mathrm{Al}_{2} \mathrm{O}_{3}$ and $\mathrm{Na}_{2} \mathrm{O}$ in this composition projection, as well as the increased $\mathrm{SiO}_{2}$ concentration. This may be beneficial for DWPF processing, because the limiting constraints for Case $\mathrm{C}$ are generally process related, rather than waste form affecting.

Table 5-3. Summary of Nominal Stage results for SB5 Case $C$ with the candidate frits.

\begin{tabular}{||l|c|c|c|c|c||}
\hline & Frit 530 & Frit 531 & Frit 532 & Frit 533 & Frit 535 \\
\hline $\begin{array}{l}\text { Operating } \\
\text { Window (\% WL) }\end{array}$ & $25-40$ & $25-40$ & $25-39$ & $28-39$ & $28-41$ \\
\hline $\begin{array}{l}\text { Lower Limiting } \\
\text { Constraint(s) }\end{array}$ & - & - & - & Homg & Homg \\
\hline $\begin{array}{l}\text { Upper Limiting } \\
\text { Constraint(s) }\end{array}$ & $\mathrm{T}_{\mathrm{L}}$ & $\mathrm{T}_{\mathrm{L}}$ & $\mathrm{T}_{\mathrm{L}}$ & $\mathrm{T}_{\mathrm{L}}$ & $\mathrm{T}_{\mathrm{L}}$, Nepheline \\
\hline
\end{tabular}

The complete results of the Nominal Stage assessment for the six candidate frits combined with SB5 Cases B and C are given in Tables A1 and A2, respectively, in Appendix A. The six candidate frits were next carried into the Variation Stage assessments.

\footnotetext{
${ }^{a}$ Note that SRNL has previously recommended that the homogeneity and high frit constraints be replaced by alumina concentration and alkali concentration constraints for sludge only processing in the DWPF. ${ }^{16}$ However, these changes have not yet been implemented in PCCS.
} 


\subsection{Variation Stage Assessments}

The focus of the Variation Stage assessments is to evaluate the performance of candidate frits when the anticipated compositional variation is applied to the sludge systems of interest. Variation was applied individually to several of the sludge components. For the major components $-\mathrm{Al}_{2} \mathrm{O}_{3}, \mathrm{Fe}_{2} \mathrm{O}_{3}, \mathrm{Na}_{2} \mathrm{O}$ and $\mathrm{U}_{3} \mathrm{O}_{8}-\mathrm{a}$ variation of $7.5 \%$ of each component's concentration was applied. A variation of $0.25 \mathrm{wt} \%$ was applied to $\mathrm{CaO}, \mathrm{MgO}, \mathrm{MnO}$ and $\mathrm{NiO}$. A variation of $0.1 \mathrm{wt} \%$ was applied to $\mathrm{SO}_{4}{ }^{2-}$ and a variation of $0.5 \mathrm{wt} \%$ was applied to $\mathrm{SiO}_{2}$. The remaining sludge components were grouped into a category called 'Others'. A variation of 0.25 wt \% was applied to the total concentration of the 'Others' components. The compositions of SB5 Cases B and C with the variation applied are given in Table 6-1.

Table 6-1. Compositions of SB5 Cases B and C with variation applied.

\begin{tabular}{||c|c|c|c|c|c||}
\hline \multirow{2}{*}{ Component } & \multirow{2}{*}{ Variation } & \multicolumn{2}{|c|}{ Case B } & \multicolumn{2}{c||}{ Case C } \\
\cline { 3 - 6 } & & Min. (wt \%) & Max. (wt \%) & Min. (wt \%) & Max. (wt \%) \\
\hline $\mathrm{Al}_{2} \mathrm{O}_{3}$ & $7.5 \%$ & 26.787 & 31.131 & 23.014 & 26.746 \\
\hline $\mathrm{CaO}$ & $0.25 \mathrm{wt} \%$ & 1.531 & 2.031 & 1.714 & 02.214 \\
\hline $\mathrm{Fe}_{2} \mathrm{O}_{3}$ & $7.5 \%$ & 21.492 & 24.977 & 23.706 & 27.550 \\
\hline $\mathrm{MgO}$ & $0.25 \mathrm{wt} \%$ & 0.927 & 1.427 & 1.048 & 1.548 \\
\hline $\mathrm{MnO}$ & $0.25 \mathrm{wt} \%$ & 4.608 & 5.108 & 5.109 & 5.609 \\
\hline $\mathrm{Na}_{2} \mathrm{O}$ & $7.5 \%$ & 22.959 & 26.682 & 22.367 & 25.994 \\
\hline $\mathrm{NiO}^{2-}$ & $0.25 \mathrm{wt} \%$ & 2.479 & 2.979 & 2.759 & 3.259 \\
\hline $\mathrm{SO}_{4}{ }^{2-}$ & $0.1 \mathrm{wt} \%$ & 0.629 & 0.829 & 0.661 & 0.861 \\
\hline $\mathrm{SiO}_{2}$ & $0.5 \mathrm{wt} \%$ & 1.385 & 2.385 & 1.580 & 2.580 \\
\hline $\mathrm{U}_{3} \mathrm{O}_{8}$ & $7.5 \%$ & 6.875 & 7.990 & 7.583 & 8.813 \\
\hline $\mathrm{Others}^{2}$ & $0.25 \mathrm{wt} \%$ & 1.159 & 1.659 & 1.299 & 1.799 \\
\hline
\end{tabular}

Statistical mixture experimental design methods were used to obtain an initial set of feasible sludge compositions based on the variation applied to SB5 Cases B and C. These methods included algorithms that were used to determine the extreme vertices (EVs) of the sludge region (the bounding compositions) for each case. After the EVs were determined for each sludge region, the Variation Stage assessments were made over the same waste loading interval (25 to $60 \% \mathrm{WL}$ ) using the DWPF PCCS models. Acceptable predicted properties for this assessment were based on satisfying the Measurement Acceptability Region (MAR) limits of PCCS. All MAR constraints were based on the current PCCS limits.

A summary of the Variation Stage results for SB5 Case B with its five candidate frits is given in Table 6-2. The operating windows shown indicate regions where all of the EVs were satisfied for the given frit/sludge combination. As is typically the case, the projected operating windows are reduced as compared to the Nominal Stage assessment. The widths of the operating windows for SB5 Case B range from 8 to 12 percentage points. The minimum WLs are limited by the high viscosity and homogeneity constraints. The maximum WLs are limited by the $\mathrm{T}_{\mathrm{L}}$ constraint. 
WSRC-STI-2008-00006

Revision 0

Table 6-2. Summary of Variation Stage results for SB5 Case B with the candidate frits.

\begin{tabular}{||l|c|c|c|c|c||}
\hline & Frit 530 & Frit 531 & Frit 532 & Frit 533 & Frit 534 \\
\hline $\begin{array}{l}\text { Operating } \\
\text { Window } \\
\text { (\% WL) }\end{array}$ & $26-37$ & $26-37$ & $26-36$ & $29-36$ & $29-36$ \\
\hline $\begin{array}{l}\text { Lower Limiting } \\
\text { Constraint(s) }\end{array}$ & highv & highv, homg & homg & homg & homg \\
\hline $\begin{array}{l}\text { Upper Limiting } \\
\text { Constraint(s) }\end{array}$ & $\mathrm{T}_{\mathrm{L}}$ & $\mathrm{T}_{\mathrm{L}}$ & $\mathrm{T}_{\mathrm{L}}$ & $\mathrm{T}_{\mathrm{L}}$ & $\mathrm{T}_{\mathrm{L}}$ \\
\hline
\end{tabular}

A summary of the Variation Stage results for SB5 Case C with its five candidate frits is given in Table 6-3. The widths of the operating windows range from 5 to 11 percentage points. The minimum WLs are limited by the homogeneity constraint for Frits 531, 533 and 535. The maximum WLs are limited by the $T_{L}$ constraint for each frit.

Table 6-3. Summary of Variation Stage results for SB5 Case C with the candidate frits.

\begin{tabular}{||l|c|c|c|c|c||}
\hline & Frit 530 & Frit 531 & Frit 532 & Frit 533 & Frit 535 \\
\hline $\begin{array}{l}\text { Operating } \\
\text { Window } \\
\text { (\% WL) }\end{array}$ & $25-35$ & $27-35$ & $25-34$ & $30-34$ & $30-36$ \\
\hline $\begin{array}{l}\text { Lower Limiting } \\
\text { Constraint(s) }\end{array}$ & - & homg & - & homg & homg \\
\hline $\begin{array}{l}\text { Upper Limiting } \\
\text { Constraint(s) }\end{array}$ & $\mathrm{T}_{\mathrm{L}}$ & $\mathrm{T}_{\mathrm{L}}$ & $\mathrm{T}_{\mathrm{L}}$ & $\mathrm{T}_{\mathrm{L}}$ & $\mathrm{T}_{\mathrm{L}}$ \\
\hline
\end{tabular}

The Variation Stage results indicate that Frits 530, 531 and 532 are reasonable candidates for both SB5 composition projections. They provide the widest projected operating windows and are limited by process constraints rather than waste form affecting constraints. The complete Variation Stage results for SB5 Case B and Case C are included in Tables A3 and A4, respectively, in Appendix A. It is important to note that these results do not include any predictions of melt rate performance. Experimental studies will be necessary to provide melt rate data to aid in any frit recommendation decisions. These frits should provide sufficient compositional freedom to allow for tailoring toward improved melt rate.

\subsection{Additional Nominal Stage Assessments at 40\% Aluminum Removal}

Additional Nominal Stage assessments were performed for the SB5 Case F projection (based on the results received from the SRNL Shielded Cells demonstration) combined with Frits 530, 531 and 532 (those that provided relatively wide operating windows for Cases B and C in the earlier assessments) over a WL interval of 25 to $60 \mathrm{wt} \%$. The results are summarized in Table 7-1. 
WSRC-STI-2008-00006

Revision 0

Table 7-1. Summary of Nominal Stage results for SB5 Case F with the candidate frits.

\begin{tabular}{||l|c|c|c||}
\hline & Frit 530 & Frit 531 & Frit 532 \\
\hline $\begin{array}{l}\text { Operating Window } \\
\text { (\% WL) }\end{array}$ & $25-41$ & $25-41$ & $25-40$ \\
\hline $\begin{array}{l}\text { Lower Limiting } \\
\text { Constraint(s) }\end{array}$ & - & - & - \\
\hline $\begin{array}{l}\text { Upper Limiting } \\
\text { Constraint(s) }\end{array}$ & $\mathrm{T}_{\mathrm{L}}$, nepheline & $\mathrm{T}_{\mathrm{L}}$, nepheline & $\mathrm{T}_{\mathrm{L}}$, nepheline \\
\hline
\end{tabular}

The assessment gives projected operating windows with widths of 16 to 17 percentage points for SB5 Case F, which is slightly larger than the operating windows projected for SB5 Cases B and C. The maximum WLs are limited by the $\mathrm{T}_{\mathrm{L}}$ and nepheline constraints. It is interesting to note that predictions of nepheline crystallization continue to be limiting for SB5 after Al-dissolution is performed. This may be partially due to high $\mathrm{Na}_{2} \mathrm{O}$ concentrations in the sludge, coupled with $\mathrm{Na}_{2} \mathrm{O}$ added with the frit. It may be possible to push the nepheline constraint to higher waste loadings by reducing the $\mathrm{Na}_{2} \mathrm{O}$ concentration in the frit, although this could negatively impact melt rate. ${ }^{\mathrm{a}}$ Alternatives for further tailoring the frit composition to avoid predictions of nepheline crystallization are likely to be available, but melt rate data is necessary to aid in evaluating the various options.

\subsection{Frit Selection for Experimental Melt Rate Studies}

Experimental melt rate studies will be performed using several of the frit compositions described above. Specifically, Frits 530, 531, 532, 533, and 534 will be procured for evaluation. Frit 535 was excluded because it was not a good candidate for SB5 Case B and it was the only frit that had an operating window limited by predictions of nepheline crystallization for SB5 Case C. SRNL will fabricate a simulated SB5 Case F Sludge Receipt and Adjustment Tank (SRAT) product to be combined with the candidate frits for testing in the Melt Rate Furnace (MRF). The MRF is a resistance heated, static melter that is used to provide comparisons of relative melting rate between various frit/sludge combinations. Results of the MRF testing will be used to evaluate the impact of the frit components, particularly $\mathrm{B}_{2} \mathrm{O}_{3}$ and $\mathrm{Na}_{2} \mathrm{O},{ }^{\mathrm{b}}$ which are expected to influence melt rate for SB5-like sludges. The results of the melt rate testing will be documented in a separate report, and will be used to help guide the frit recommendation process as the final SB5 composition becomes better known.

\footnotetext{
${ }^{\text {a }}$ High $\mathrm{Na}_{2} \mathrm{O}$ concentration frits were previously recommended for improved melt rates in DWPF processing of high $\mathrm{Fe}_{2} \mathrm{O}_{3}$ / low $\mathrm{Al}_{2} \mathrm{O}_{3}$ concentration (PUREX-type) sludges.

${ }^{\mathrm{b}}$ Selection of these frits for melt rate testing was also due in part to the range of $\mathrm{B}_{2} \mathrm{O}_{3}\left(10-16\right.$ wt \%) and $\mathrm{Na}_{2} \mathrm{O}(4-8$ wt \%) concentrations that they represent. The relatively wide ranges available for these components are likely to be advantageous for tailoring the frit composition for enhanced melt rate.
} 
WSRC-STI-2008-00006

Revision 0

\subsection{Summary}

Composition projections for SB5 were developed to evaluate possible impacts of the Aldissolution process on the availability of viable frit compositions for vitrification at the DWPF. The study included two projected SB5 compositions that bound potential outcomes (or degrees of effectiveness) of the Al-dissolution process, as well as a nominal SB5 composition projection based on the results of the recent Al-dissolution demonstration at SRNL. The bounding projections, representing 25\% and 50\% removal of Al, were the focus of a paper study to assess the availability of candidate frits and their ability to tolerate the anticipated variation in sludge composition. A Nominal Stage assessment was used to evaluate the two SB5 projections combined with an array of 19,305 frit compositions over a range of WL values against the DWPF process control models. The Nominal Stage results allowed for the down-selection of a small number of frits that provided reasonable projected operating windows (typically 25 to $40 \mathrm{wt} \%$ ) and permitted some compositional flexibility (i.e., the ability to further tailor the frit to improve melt rate).

Variation Stage assessments were then performed using the down-selected frits and the two SB5 composition projections with variation applied to each sludge component. The Variation Stage results showed that the operating windows were somewhat reduced in width, as expected when variation is applied. Three of the down-selected frits continued to perform acceptably for this study for both SB5 projections through the Variation Stage, providing WL windows of approximately 26 to $35 \mathrm{wt} \%$. The maximum WLs were limited by a processing constraint, $\mathrm{T}_{\mathrm{L}}$, rather than a waste form affecting constraint (e.g., nepheline crystallization) in the Variation Stage assessments.

While acceptable, the operating windows are relatively small for the variation stage assessments for the selected frits. However, the compositional variation of the frits should provide opportunity to explore important relationships between frit composition and melt rate for SB5like systems.

Subsequent Nominal Stage assessments were performed with an updated SB5 projection based on the results of the Al-dissolution demonstration performed in the SRNL Shielded Cells facility (representing 40\% removal of $\mathrm{Al}$ ). The three frits identified in the earlier paper studies continued to perform acceptably with this updated projection. The available operating windows were slightly wider, although maximum WL was limited by both the $T_{L}$ and nepheline constraints for all three frits.

These paper study assessments have identified candidate frits which, when combined with the current, projected SB5 compositions after Al-dissolution, have projected operating windows that should be reasonable for DWPF processing. Changes in the projected SB5 composition are anticipated before processing begins at the DWPF, which will likely require additional paper study assessments as well as experimental frit development studies. This study identifies several frits which provide insight into potential operating windows for SB5 vitrification in DWPF. However, until experimental studies can be performed to gain information on melt rate and other parameters needed to optimize frit selection, no final frit recommendation can be made.

No information regarding melt rate can be inferred from the paper study results. Experimental studies to evaluate this critical factor in DWPF processing must be performed before a frit recommendation could be made for any projected sludge composition. Five frit compositions were identified for melt rate testing at SRNL with the simulated SB5 Case F SRAT product. The 
results of these tests will be used to evaluate the impact of the frit components - particularly $\mathrm{B}_{2} \mathrm{O}_{3}$ and $\mathrm{Na}_{2} \mathrm{O}$ - that are expected to influence melt rate for SB5-like sludges. The results of the melt rate testing will be documented in a separate report, and will be used to help guide the frit recommendation process when the final SB5 composition becomes clearer. 
WSRC-STI-2008-00006

Revision 0

\subsection{References}

1. Hay, M. S., J. M. Pareizs, C. J. Bannochie, M. E. Stone, D. R. Click and D. J. McCabe, "Characterization and Aluminum Dissolution Demonstration with a 3 Liter Tank 51H Sample," U.S. Department of Energy Report WSRC-STI-2007-00697, Revision 0, Washington Savannah River Company, Aiken, SC (2008).

2. Peeler, D. K. and T. B. Edwards, "Frit Development for Sludge Batch 3," U.S. Department of Energy Report WSRC-TR-2002-00491, Revision 0, Westinghouse Savannah River Company, Aiken, SC (2002).

3. Culbertson, B. H., "Sludge Batch 5 Frit Optimization,” U.S. Department of Energy Report HLW-DWPF-TTR-2007-0007, Revision 0, Washington Savannah River Company, Aiken, SC (2006).

4. Peeler, D. K., "Sludge Batch 5 Frit Optimization,” U.S. Department of Energy Report WSRCSTI-2006-00321, Washington Savannah River Company, Aiken, SC (2007).

5. Choi, A. S., "Aluminum Dissolution Flowsheet Modeling in Support of SB5 Frit Development,” U.S. Department of Energy Report WSRC-STI-2008-00001, Revision 0, Washington Savannah River Company, Aiken, SC (2008).

6. Pareizs, J. M., C. J. Bannochie, M. J. Barnes, N. E. Bibler, D. R. Click, E. K. Hansen, D. P. Lambert and M. E. Stone, "Demonstration of the DWPF Flowsheet in the SRNL Shielded Cells in Support of Sludge Batch 4 Qualification," U.S. Department of Energy Report WSRC-STI-200700053, Revision 0, Washington Savannah River Company, Aiken, SC (2007).

7. Lambert, D. P. and C. J. Bannochie, "Results from Analysis of Tank 7F Samples Taken in November 2006 and April 2007,” U.S. Department of Energy Report SRNL-PSE-2007-00118, Revision 1, Washington Savannah River Company, Aiken, SC (2007).

8. Fox, K. M., T. B. Edwards, D. R. Best, I. A. Reamer and R. J. Workman, "Sludge Batch 5 (SB5): Selection of Candidate Frits and Characterization of Preliminary Glass Systems," U.S. Department of Energy Report WSRC-STI-2007-00418, Revision 0, Washington Savannah River Company, Aiken, SC (2007).

9. Fox, K. M., T. B. Edwards and D. K. Peeler, "Sludge Batch 4 (SB4) After a Tank 40 Decant: Candidate Frits, MAR Assessments, and Glasses for a Variability Study," U.S. Department of Energy Report WSRC-STI-2006-00305, Revision 0, Washington Savannah River Company, Aiken, SC (2006).

10. Fox, K. M., T. B. Edwards, D. K. Peeler, D. R. Best, I. A. Reamer and R. J. Workman, "Durability and Nepheline Crystallization Study for High Level Waste (HLW) Sludge Batch 4 (SB4) Glasses Formulated with Frit 503," U.S. Department of Energy Report WSRC-STI-200600009, Revision 0, Washington Savannah River Company, Aiken, SC (2006).

11. Gillam Jr., J. H., K. M. Fox, T. B. Edwards and D. K. Peeler, "Frit Selection to Support Steklo Metallicheskie Konstruktsii (SMK) Melter Testing with SRNL Feeds,” U.S. Department of Energy Report WSRC-STI-2007-00363, Revision 0, Washington Savannah River Company, Aiken, SC (2007). 
12. Peeler, D. K. and T. B. Edwards, "Frit Development Effort for SB4: Nominal and Variation Stage Assessments," U.S. Department of Energy Report WSRC-TR-2005-00372, Revision 0, Westinghouse Savannah River Company, Aiken, SC (2005).

13. Peeler, D. K. and T. B. Edwards, "Frit Development Efforts for Sludge Batch 4: ModelBased Assessments,” U.S. Department of Energy Report WSRC-TR-2005-00103, Revision 0, Westinghouse Savannah River Company, Aiken, SC (2005).

14. Peeler, D. K. and T. B. Edwards, "High $\mathrm{B}_{2} \mathrm{O}_{3} / \mathrm{Fe}_{2} \mathrm{O}_{3}$-based Frits: MAR Assessments for Sludge Batch 4 (SB4)," U.S. Department of Energy Report WSRC-TR-2006-00181, Revision 0, Washington Savannah River Company, Aiken, SC (2006).

15. Peeler, D. K. and T. B. Edwards, "Model Based Assessments of the Final SB4 Projections Compositions Leading to the Frit Recommendation," U.S. Department of Energy Report WSRCTR-2006-00269, Revision 0, Washington Savannah River Company, Aiken, SC (2006).

16. Herman, C. C., T. B. Edwards, D. R. Best, D. M. Marsh and R. J. Workman, "Reduction of Constraints: Phase 2 Experimental Assessment for Sludge-Only Processing," U.S. Department of Energy Report WSRC-TR-2002-00482, Revision 0, Westinghouse Savannah River Company, Aiken, SC (2002). 
WSRC-STI-2008-00006

Revision 0

Appendix A

Complete Results for the Nominal Stage Assessments 
Table A1. Complete Nominal Stage results for Sludge Case B with Frits 530, 531, 532, 533 and 534.

\begin{tabular}{|c|c|c|c|c|c|}
\hline WL & Frit 530 & Frit 531 & Frit 532 & Frit 533 & Frit 534 \\
\hline 25 & & & & Homg hFrit & Homg hFrit \\
\hline 26 & & & & Homg & Homg \\
\hline \multicolumn{6}{|l|}{27} \\
\hline \multicolumn{6}{|l|}{28} \\
\hline \multicolumn{6}{|l|}{29} \\
\hline \multicolumn{6}{|l|}{30} \\
\hline \multicolumn{6}{|l|}{31} \\
\hline \multicolumn{6}{|l|}{32} \\
\hline \multicolumn{6}{|l|}{33} \\
\hline \multicolumn{6}{|l|}{34} \\
\hline \multicolumn{6}{|l|}{35} \\
\hline \multicolumn{6}{|l|}{36} \\
\hline \multicolumn{6}{|l|}{37} \\
\hline \multicolumn{6}{|l|}{38} \\
\hline \multicolumn{6}{|l|}{39} \\
\hline 40 & & & Neph & Neph & \\
\hline 41 & Neph & Neph & Neph & Neph & \\
\hline 42 & Neph & Neph & Neph & Neph & \\
\hline 43 & Neph & Neph & $\mathrm{T}_{\mathrm{L}} \mathrm{Neph}$ & $\mathrm{T}_{\mathrm{L}} \mathrm{Neph}$ & $\mathrm{T}_{\mathrm{L}} \mathrm{Neph}$ \\
\hline 44 & $\mathrm{~T}_{\mathrm{L}} \mathrm{Neph}$ & $\mathrm{T}_{\mathrm{L}} \mathrm{Neph}$ & $\mathrm{T}_{\mathrm{L}} \mathrm{Neph}$ & $\mathrm{T}_{\mathrm{L}} \mathrm{Neph}$ & $\mathrm{T}_{\mathrm{L}} \mathrm{Neph}$ \\
\hline 45 & $\mathrm{~T}_{\mathrm{L}} \mathrm{Neph}$ & $\mathrm{T}_{\mathrm{L}} \mathrm{Neph}$ & $\mathrm{T}_{\mathrm{L}} \mathrm{Neph}$ & $\mathrm{T}_{\mathrm{L}} \mathrm{Neph}$ & $\mathrm{T}_{\mathrm{L}} \mathrm{Neph}$ \\
\hline 46 & $\mathrm{~T}_{\mathrm{L}} \mathrm{Neph}$ & $\mathrm{T}_{\mathrm{L}} \mathrm{Neph}$ & $\mathrm{T}_{\mathrm{L}} \mathrm{Neph}$ & $\mathrm{T}_{\mathrm{L}} \mathrm{Neph}$ & $\mathrm{T}_{\mathrm{L}} \mathrm{Neph}$ \\
\hline 47 & $\mathrm{~T}_{\mathrm{L}} \mathrm{Neph}$ & $\mathrm{T}_{\mathrm{L}} \mathrm{Neph}$ & $\mathrm{T}_{\mathrm{L}} \mathrm{Neph}$ & $\mathrm{T}_{\mathrm{L}} \mathrm{Neph}$ & $\mathrm{T}_{\mathrm{L}} \mathrm{Neph}$ \\
\hline 48 & $\mathrm{~T}_{\mathrm{L}} \mathrm{Neph}$ & $\mathrm{T}_{\mathrm{L}} \mathrm{Neph}$ & $\mathrm{T}_{\mathrm{L}} \mathrm{Neph}$ & $\mathrm{T}_{\mathrm{L}} \mathrm{Neph}$ & $\mathrm{T}_{\mathrm{L}}$ lowv Neph \\
\hline 49 & $\mathrm{~T}_{\mathrm{L}} \mathrm{Neph}$ & $\mathrm{T}_{\mathrm{L}} \mathrm{Neph}$ & $\mathrm{T}_{\mathrm{L}} \mathrm{Neph}$ & $\mathrm{T}_{\mathrm{L}} \mathrm{Neph}$ & $T_{L}$ lowv Neph \\
\hline 50 & $\mathrm{~T}_{\mathrm{L}} \mathrm{Neph}$ & $\mathrm{T}_{\mathrm{L}} \mathrm{Neph}$ & $\mathrm{T}_{\mathrm{L}} \mathrm{Neph}$ & $\mathrm{T}_{\mathrm{L}} \mathrm{Neph}$ & $\mathrm{T}_{\mathrm{L}}$ lowv Neph \\
\hline 51 & $\mathrm{~T}_{\mathrm{L}} \mathrm{Neph}$ & $\mathrm{T}_{\mathrm{L}} \mathrm{Neph}$ & $\mathrm{T}_{\mathrm{L}} \mathrm{Neph}$ & $\mathrm{T}_{\mathrm{L}} \mathrm{Neph}$ & $\mathrm{T}_{\mathrm{L}}$ lowv Neph \\
\hline 52 & $\mathrm{~T}_{\mathrm{L}} \mathrm{Neph}$ & $\mathrm{T}_{\mathrm{L}} \mathrm{Neph}$ & $\mathrm{T}_{\mathrm{L}} \mathrm{Neph}$ & $\mathrm{T}_{\mathrm{L}}$ Neph & $\mathrm{T}_{\mathrm{L}}$ lowv Neph \\
\hline 53 & $\mathrm{~T}_{\mathrm{L}}$ lowv Neph & $\mathrm{T}_{\mathrm{L}}$ lowv Neph & $\mathrm{T}_{\mathrm{L}}$ lowv Neph & $\mathrm{T}_{\mathrm{L}}$ lowv Neph & $\mathrm{T}_{\mathrm{L}}$ lowv Neph \\
\hline 54 & $\mathrm{~T}_{\mathrm{L}}$ lowv Neph & $\mathrm{T}_{\mathrm{L}}$ lowv Neph & $\mathrm{T}_{\mathrm{L}}$ lowv Neph & $\mathrm{T}_{\mathrm{L}}$ lowv Neph & $\mathrm{T}_{\mathrm{L}}$ lowv Neph \\
\hline 55 & $\mathrm{~T}_{\mathrm{L}}$ lowv $\mathrm{SO}_{4}{ }^{2-} \mathrm{Neph}$ & $\mathrm{T}_{\mathrm{L}}$ lowv $\mathrm{SO}_{4}{ }^{2-} \mathrm{Neph}$ & $\mathrm{T}_{\mathrm{L}}$ lowv $\mathrm{SO}_{4}{ }^{2-} \mathrm{Neph}$ & $\mathrm{T}_{\mathrm{L}}$ lowv $\mathrm{SO}_{4}^{2-} \mathrm{Neph}$ & $\mathrm{T}_{\mathrm{L}}$ lowv $\mathrm{SO}_{4}{ }^{2-} \mathrm{Neph}$ \\
\hline 56 & $\mathrm{~T}_{\mathrm{L}}$ lowv $\mathrm{SO}_{4}{ }^{2-} \mathrm{Neph}$ & $\mathrm{T}_{\mathrm{L}}$ lowv $\mathrm{SO}_{4}{ }^{2-} \mathrm{Neph}$ & $\mathrm{T}_{\mathrm{L}}$ lowv $\mathrm{SO}_{4}{ }^{2-} \mathrm{Neph}$ & $\mathrm{T}_{\mathrm{L}}$ lowv $\mathrm{SO}_{4}^{2-} \mathrm{Neph}$ & $\mathrm{T}_{\mathrm{L}}$ lowv $\mathrm{SO}_{4}{ }^{2-} \mathrm{Neph}$ \\
\hline 57 & $\mathrm{~T}_{\mathrm{L}}$ lowv $\mathrm{SO}_{4}{ }^{2-} \mathrm{Neph}$ & $\mathrm{T}_{\mathrm{L}}$ lowv $\mathrm{SO}_{4}{ }^{2-} \mathrm{Neph}$ & $\mathrm{T}_{\mathrm{L}}$ lowv $\mathrm{SO}_{4}{ }^{2-} \mathrm{Neph}$ & $\mathrm{T}_{\mathrm{L}}$ lowv $\mathrm{SO}_{4}{ }^{2-} \mathrm{Neph}$ & $\mathrm{T}_{\mathrm{L}}$ lowv $\mathrm{SO}_{4}{ }^{2-} \mathrm{Neph}$ \\
\hline 58 & $\mathrm{~T}_{\mathrm{L}}$ lowv $\mathrm{SO}_{4}{ }^{2-} \mathrm{Neph}$ & $\mathrm{T}_{\mathrm{L}}$ lowv $\mathrm{SO}_{4}{ }^{2-} \mathrm{Neph}$ & $\mathrm{T}_{\mathrm{L}}$ lowv $\mathrm{SO}_{4}{ }^{2-} \mathrm{Neph}$ & $\mathrm{T}_{\mathrm{L}}$ lowv $\mathrm{SO}_{4}^{2-} \mathrm{Neph}$ & $\mathrm{T}_{\mathrm{L}}$ lowv $\mathrm{SO}_{4}{ }^{2-} \mathrm{Neph}$ \\
\hline 59 & $\mathrm{~T}_{\mathrm{L}}$ lowv $\mathrm{SO}_{4}{ }^{2-} \mathrm{Neph}$ & $\mathrm{T}_{\mathrm{L}}$ lowv $\mathrm{SO}_{4}{ }^{2-} \mathrm{Neph}$ & $\mathrm{T}_{\mathrm{L}}$ lowv $\mathrm{SO}_{4}{ }^{2-} \mathrm{Neph}$ & $\mathrm{T}_{\mathrm{L}}$ lowv $\mathrm{SO}_{4}{ }^{2-} \mathrm{Neph}$ & $\mathrm{T}_{\mathrm{L}}$ lowv $\mathrm{SO}_{4}{ }^{2-} \mathrm{Neph}$ \\
\hline 60 & $\mathrm{~T}_{\mathrm{L}}$ lowv $\mathrm{SO}_{4}{ }^{2-} \mathrm{Neph}$ & $\mathrm{T}_{\mathrm{L}}$ lowv $\mathrm{SO}_{4}{ }^{2-} \mathrm{Neph}$ & $\mathrm{T}_{\mathrm{L}}$ lowv $\mathrm{SO}_{4}{ }^{2-} \mathrm{Neph}$ & $\mathrm{T}_{\mathrm{L}}$ lowv $\mathrm{SO}_{4}{ }^{2-} \mathrm{Neph}$ & $\mathrm{T}_{\mathrm{L}}$ lowv $\mathrm{SO}_{4}{ }^{2-} \mathrm{Neph}$ \\
\hline
\end{tabular}


Table A2. Complete Nominal Stage results for Sludge Case C with Frits 530, 531, 532, 533 and 535.

\begin{tabular}{|c|c|c|c|c|c|}
\hline $\mathbf{W}_{\mathrm{L}}$ & Frit 530 & Frit 531 & Frit 532 & Frit 533 & Frit 535 \\
\hline 25 & & & & Homg & Homg \\
\hline 26 & & & & Homg & Homg \\
\hline 27 & & & & Homg & Homg \\
\hline \multicolumn{6}{|l|}{28} \\
\hline \multicolumn{6}{|l|}{29} \\
\hline \multicolumn{6}{|l|}{30} \\
\hline \multicolumn{6}{|l|}{31} \\
\hline \multicolumn{6}{|l|}{32} \\
\hline \multicolumn{6}{|l|}{33} \\
\hline \multicolumn{6}{|l|}{34} \\
\hline \multicolumn{6}{|l|}{35} \\
\hline \multicolumn{6}{|l|}{36} \\
\hline \multicolumn{6}{|l|}{37} \\
\hline \multicolumn{6}{|l|}{38} \\
\hline \multicolumn{6}{|l|}{39} \\
\hline 40 & & & $\mathrm{~T}_{\mathrm{L}}$ & $\mathrm{T}_{\mathrm{L}}$ & \\
\hline 41 & $\mathrm{~T}_{\mathrm{L}}$ & $\mathrm{T}_{\mathrm{L}}$ & $\mathrm{T}_{\mathrm{L}}$ & $\mathrm{T}_{\mathrm{L}}$ & \\
\hline 42 & $\mathrm{~T}_{\mathrm{L}}$ & $\mathrm{T}_{\mathrm{L}}$ & $\mathrm{T}_{\mathrm{L}}$ & $\mathrm{T}_{\mathrm{L}} \mathrm{Neph}$ & $\mathrm{T}_{\mathrm{L}} \mathrm{Neph}$ \\
\hline 43 & $\mathrm{~T}_{\mathrm{L}} \mathrm{Neph}$ & $\mathrm{T}_{\mathrm{L}} \mathrm{Neph}$ & $\mathrm{T}_{\mathrm{L}} \mathrm{Neph}$ & $\mathrm{T}_{\mathrm{L}} \mathrm{Neph}$ & $\mathrm{T}_{\mathrm{L}} \mathrm{Neph}$ \\
\hline 44 & $\mathrm{~T}_{\mathrm{L}} \mathrm{Neph}$ & $\mathrm{T}_{\mathrm{L}} \mathrm{Neph}$ & $\mathrm{T}_{\mathrm{L}} \mathrm{Neph}$ & $\mathrm{T}_{\mathrm{L}} \mathrm{Neph}$ & $\mathrm{T}_{\mathrm{L}}$ lowv Neph \\
\hline 45 & $\mathrm{~T}_{\mathrm{L}}$ Neph & $\mathrm{T}_{\mathrm{L}} \mathrm{Neph}$ & $\mathrm{T}_{\mathrm{L}} \mathrm{Neph}$ & $\mathrm{T}_{\mathrm{L}} \mathrm{Neph}$ & $\mathrm{T}_{\mathrm{L}}$ lowv Neph \\
\hline 46 & $\mathrm{~T}_{\mathrm{L}} \mathrm{Neph}$ & $\mathrm{T}_{\mathrm{L}} \mathrm{Neph}$ & $\mathrm{T}_{\mathrm{L}} \mathrm{Neph}$ & $\mathrm{T}_{\mathrm{L}} \mathrm{Neph}$ & $\mathrm{T}_{\mathrm{L}}$ lowv Neph \\
\hline 47 & $\mathrm{~T}_{\mathrm{L}} \mathrm{Neph}$ & $\mathrm{T}_{\mathrm{L}} \mathrm{Neph}$ & $\mathrm{T}_{\mathrm{L}} \mathrm{Neph}$ & $\mathrm{T}_{\mathrm{L}} \mathrm{Neph}$ & $\mathrm{T}_{\mathrm{L}}$ lowv Neph \\
\hline 48 & $\mathrm{~T}_{\mathrm{L}} \mathrm{Neph}$ & $\mathrm{T}_{\mathrm{L}} \mathrm{Neph}$ & $\mathrm{T}_{\mathrm{L}} \mathrm{Neph}$ & $\mathrm{T}_{\mathrm{L}} \mathrm{Neph}$ & $\mathrm{T}_{\mathrm{L}}$ lowv Neph \\
\hline 49 & $\mathrm{~T}_{\mathrm{L}}$ lowv Neph & $T_{L}$ lowv Neph & $T_{L}$ lowv Neph & $T_{L}$ lowv Neph & $\mathrm{T}_{\mathrm{L}}$ lowv Neph \\
\hline 50 & $\mathrm{~T}_{\mathrm{L}}$ lowv Neph & $\mathrm{T}_{\mathrm{L}}$ lowv Neph & $\mathrm{T}_{\mathrm{L}}$ lowv Neph & $\mathrm{T}_{\mathrm{L}}$ lowv Neph & $\mathrm{T}_{\mathrm{L}}$ lowv Neph \\
\hline 51 & $\mathrm{~T}_{\mathrm{L}}$ lowv Neph & $\mathrm{T}_{\mathrm{L}}$ lowv Neph & $\mathrm{T}_{\mathrm{L}}$ lowv Neph & $\mathrm{T}_{\mathrm{L}}$ lowv Neph & $\mathrm{T}_{\mathrm{L}}$ lowv Neph \\
\hline 52 & $\mathrm{~T}_{\mathrm{L}}$ lowv Neph & $\mathrm{T}_{\mathrm{L}}$ lowv Neph & $T_{L}$ lowv Neph & $\mathrm{T}_{\mathrm{L}}$ lowv Neph & $\mathrm{T}_{\mathrm{L}}$ lowv Neph \\
\hline 53 & $\mathrm{~T}_{\mathrm{L}}$ lowv $\mathrm{SO}_{4}{ }^{2-} \mathrm{Neph}$ & $\mathrm{T}_{\mathrm{L}}$ lowv $\mathrm{SO}_{4}{ }^{2-} \mathrm{Neph}$ & $\mathrm{T}_{\mathrm{L}}$ lowv $\mathrm{SO}_{4}^{2-} \mathrm{Neph}$ & $\mathrm{T}_{\mathrm{L}}$ lowv $\mathrm{SO}_{4}^{2-} \mathrm{Neph}$ & $\mathrm{T}_{\mathrm{L}}$ lowv $\mathrm{SO}_{4}{ }^{2-} \mathrm{Neph}$ \\
\hline 54 & $\mathrm{~T}_{\mathrm{L}}$ lowv $\mathrm{SO}_{4}{ }^{2-} \mathrm{Neph}$ & $\mathrm{T}_{\mathrm{L}}$ lowv $\mathrm{SO}_{4}{ }^{2-} \mathrm{Neph}$ & $\mathrm{T}_{\mathrm{L}}$ lowv $\mathrm{SO}_{4}{ }^{2-} \mathrm{Neph}$ & $\mathrm{T}_{\mathrm{L}}$ lowv $\mathrm{SO}_{4}{ }^{2-} \mathrm{Neph}$ & $\mathrm{T}_{\mathrm{L}}$ lowv $\mathrm{SO}_{4}{ }^{2-} \mathrm{Neph}$ \\
\hline 55 & $\mathrm{~T}_{\mathrm{L}}$ lowv $\mathrm{SO}_{4}{ }^{2-} \mathrm{Neph}$ & $\mathrm{T}_{\mathrm{L}}$ lowv $\mathrm{SO}_{4}{ }^{2-} \mathrm{Neph}$ & $\mathrm{T}_{\mathrm{L}}$ lowv $\mathrm{SO}_{4}{ }^{2-} \mathrm{Neph}$ & $\mathrm{T}_{\mathrm{L}}$ lowv $\mathrm{SO}_{4}{ }^{2-} \mathrm{Neph}$ & $\mathrm{T}_{\mathrm{L}}$ lowv $\mathrm{SO}_{4}{ }^{2-} \mathrm{Neph}$ \\
\hline 56 & $\mathrm{~T}_{\mathrm{L}}$ lowv $\mathrm{SO}_{4}^{2-} \mathrm{Neph}$ & $\mathrm{T}_{\mathrm{L}}$ lowv $\mathrm{SO}_{4}^{2-} \mathrm{Neph}$ & $\mathrm{T}_{\mathrm{L}}$ lowv $\mathrm{SO}_{4}^{2-} \mathrm{Neph}$ & $\mathrm{T}_{\mathrm{L}}$ lowv $\mathrm{SO}_{4}^{2-} \mathrm{Neph}$ & $\mathrm{T}_{\mathrm{L}}$ lowv $\mathrm{SO}_{4}^{2-} \mathrm{Neph}$ \\
\hline 57 & $\mathrm{~T}_{\mathrm{L}}$ lowv $\mathrm{SO}_{4}{ }^{2-} \mathrm{Cr}_{2} \mathrm{O}_{3} \mathrm{Neph}$ & $\mathrm{T}_{\mathrm{L}}$ lowv $\mathrm{SO}_{4}{ }^{2-} \mathrm{Cr}_{2} \mathrm{O}_{3} \mathrm{Neph}$ & $\mathrm{T}_{\mathrm{L}}$ lowv $\mathrm{SO}_{4}^{2-} \mathrm{Cr}_{2} \mathrm{O}_{3} \mathrm{Neph}$ & $\mathrm{T}_{\mathrm{L}}$ lowv $\mathrm{SO}_{4}{ }^{2-} \mathrm{Cr}_{2} \mathrm{O}_{3} \mathrm{Neph}$ & $\mathrm{T}_{\mathrm{L}}$ lowv $\mathrm{SO}_{4}{ }^{2-} \mathrm{Cr}_{2} \mathrm{O}_{3} \mathrm{Neph}$ \\
\hline 58 & $\mathrm{~T}_{\mathrm{L}}$ lowv $\mathrm{SO}_{4}{ }^{2-} \mathrm{Cr}_{2} \mathrm{O}_{3} \mathrm{Neph}$ & $\mathrm{T}_{\mathrm{L}}$ lowv $\mathrm{SO}_{4}{ }^{2-} \mathrm{Cr}_{2} \mathrm{O}_{3} \mathrm{Neph}$ & $\mathrm{T}_{\mathrm{L}}$ lowv $\mathrm{SO}_{4}{ }^{2-} \mathrm{Cr}_{2} \mathrm{O}_{3} \mathrm{Neph}$ & $\mathrm{T}_{\mathrm{L}}$ lowv $\mathrm{SO}_{4}{ }^{2-} \mathrm{Cr}_{2} \mathrm{O}_{3} \mathrm{Neph}$ & $\mathrm{T}_{\mathrm{L}}$ lowv $\mathrm{SO}_{4}{ }^{2-} \mathrm{Cr}_{2} \mathrm{O}_{3} \mathrm{Neph}$ \\
\hline 59 & $\mathrm{~T}_{\mathrm{L}}$ lowv $\mathrm{SO}_{4}{ }^{2-} \mathrm{Cr}_{2} \mathrm{O}_{3} \mathrm{Neph}$ & $\mathrm{T}_{\mathrm{L}}$ lowv $\mathrm{SO}_{4}{ }^{2-} \mathrm{Cr}_{2} \mathrm{O}_{3} \mathrm{Neph}$ & $\mathrm{T}_{\mathrm{L}}$ lowv $\mathrm{SO}_{4}{ }^{2-} \mathrm{Cr}_{2} \mathrm{O}_{3} \mathrm{Neph}$ & $\mathrm{T}_{\mathrm{L}}$ lowv $\mathrm{SO}_{4}{ }^{2-} \mathrm{Cr}_{2} \mathrm{O}_{3} \mathrm{Neph}$ & $\mathrm{T}_{\mathrm{L}}$ lowv $\mathrm{SO}_{4}^{2-} \mathrm{Cr}_{2} \mathrm{O}_{3} \mathrm{Neph}$ \\
\hline 60 & $\mathrm{~T}_{\mathrm{L}}$ lowv $\mathrm{SO}_{4}{ }^{2-} \mathrm{Cr}_{2} \mathrm{O}_{3} \mathrm{Neph}$ & $\mathrm{T}_{\mathrm{L}}$ lowv $\mathrm{SO}_{4}{ }^{2-} \mathrm{Cr}_{2} \mathrm{O}_{3} \mathrm{Neph}$ & $\mathrm{T}_{\mathrm{L}}$ lowv $\mathrm{SO}_{4}{ }^{2-} \mathrm{Cr}_{2} \mathrm{O}_{3} \mathrm{Neph}$ & $\mathrm{T}_{\mathrm{L}}$ lowv $\mathrm{SO}_{4}{ }^{2-} \mathrm{Cr}_{2} \mathrm{O}_{3} \mathrm{Neph}$ & $\mathrm{T}_{\mathrm{L}}$ lowv $\mathrm{SO}_{4}{ }^{2-} \mathrm{Cr}_{2} \mathrm{O}_{3} \mathrm{Neph}$ \\
\hline
\end{tabular}


Table A3. Results of the Variation Stage Assessment for sludge Case B with the five candidate frits.

\begin{tabular}{|c|c|c|c|c|c|c|c|c|c|c|}
\hline \multirow[b]{2}{*}{ WL } & \multicolumn{2}{|r|}{ Frit 530} & \multicolumn{2}{|r|}{ Frit 531} & \multicolumn{2}{|r|}{ Frit 532} & \multicolumn{2}{|r|}{ Frit 533} & \multicolumn{2}{|r|}{ Frit 534} \\
\hline & $\begin{array}{l}\text { Percent } \\
\text { of EVs }\end{array}$ & Limiting Constraint(s) & $\begin{array}{l}\text { Percent } \\
\text { of EVs }\end{array}$ & Limiting Constraint(s) & $\begin{array}{l}\text { Percent } \\
\text { of EVs }\end{array}$ & Limiting Constraint(s) & $\begin{array}{l}\text { Percent } \\
\text { of EVs }\end{array}$ & Limiting Constraint(s) & $\begin{array}{l}\text { Percent } \\
\text { of EVs }\end{array}$ & Limiting Constraint(s) \\
\hline 25 & 99.8 & highv & 99.6 & highv Homg & 99.8 & Homg & 22.5 & highv Homg hFrit & 22.6 & Homg hFrit \\
\hline 26 & 100.0 & & 100.0 & & 100.0 & & 41.6 & highv Homg & 41.6 & Homg \\
\hline 27 & 100.0 & & 100.0 & & 100.0 & & 89.0 & Homg & 89.0 & Homg \\
\hline 28 & 100.0 & & 100.0 & & 100.0 & & 98.5 & Homg & 98.5 & Homg \\
\hline 29 & 100.0 & & 100.0 & & 100.0 & & 100.0 & & 100.0 & \\
\hline 30 & 100.0 & & 100.0 & & 100.0 & & 100.0 & & 100.0 & \\
\hline 31 & 100.0 & & 100.0 & & 100.0 & & 100.0 & & 100.0 & \\
\hline 32 & 100.0 & & 100.0 & & 100.0 & & 100.0 & & 100.0 & \\
\hline 33 & 100.0 & & 100.0 & & 100.0 & & 100.0 & & 100.0 & \\
\hline 34 & 100.0 & & 100.0 & & 100.0 & & 100.0 & & 100.0 & \\
\hline 35 & 100.0 & & 100.0 & & 100.0 & & 100.0 & & 100.0 & \\
\hline 36 & 100.0 & & 100.0 & & 100.0 & & 100.0 & & 100.0 & \\
\hline 37 & 100.0 & & 100.0 & & 99.1 & $\overline{T_{L}}$ & 99.4 & $\overline{T_{L}}$ & 97.9 & $\mathrm{~T}_{\mathrm{L}}$ \\
\hline 38 & 99.7 & $\mathrm{~T}_{\mathrm{L}}$ & 99.8 & $\mathrm{~T}_{\mathrm{L}}$ & 86.1 & $\mathrm{~T}_{\mathrm{L}}$ Neph & 73.3 & $\mathrm{~T}_{\mathrm{L}}$ Neph & 92.8 & $T_{L}$ \\
\hline 39 & 76.2 & $\mathrm{~T}_{\mathrm{L}}$ Neph & 83.2 & $\mathrm{~T}_{\mathrm{L}}$ Neph & 58.3 & $\mathrm{~T}_{\mathrm{L}} \mathrm{Neph}$ & 42.5 & $\mathrm{~T}_{\mathrm{L}} \mathrm{Neph}$ & 83.0 & $\mathrm{~T}_{\mathrm{L}}$ \\
\hline 40 & 45.2 & $\mathrm{~T}_{\mathrm{L}} \mathrm{Neph}$ & 59.3 & $\mathrm{~T}_{\mathrm{L}} \mathrm{Neph}$ & 17.5 & $\mathrm{~T}_{\mathrm{L}} \mathrm{Neph}$ & 1.3 & $\mathrm{~T}_{\mathrm{L}} \mathrm{Neph}$ & 74.0 & $\mathrm{~T}_{\mathrm{L}}$ \\
\hline 41 & 2.2 & $\mathrm{~T}_{\mathrm{L}} \mathrm{Neph}$ & 6.2 & $\mathrm{~T}_{\mathrm{L}} \mathrm{Neph}$ & 0.1 & $\mathrm{~T}_{\mathrm{L}} \mathrm{Neph}$ & 0.0 & $\mathrm{~T}_{\mathrm{L}} \mathrm{Neph}$ & 42.9 & $\mathrm{~T}_{\mathrm{L}} \mathrm{Neph}$ \\
\hline 42 & 0.0 & $\mathrm{~T}_{\mathrm{L}} \mathrm{Neph}$ & 0.0 & $\mathrm{~T}_{\mathrm{L}} \mathrm{Neph}$ & 0.0 & $\mathrm{~T}_{\mathrm{L}} \mathrm{Neph}$ & 0.0 & $\mathrm{~T}_{\mathrm{L}} \mathrm{Neph}$ & 13.6 & $\mathrm{~T}_{\mathrm{L}}$ lowv Neph \\
\hline 43 & 0.0 & $\mathrm{~T}_{\mathrm{L}} \mathrm{Neph}$ & 0.0 & $\mathrm{~T}_{\mathrm{L}}$ Neph & 0.0 & $\mathrm{~T}_{\mathrm{L}} \mathrm{Neph}$ & 0.0 & $\mathrm{~T}_{\mathrm{L}} \mathrm{Neph}$ & 0.1 & $\mathrm{~T}_{\mathrm{L}}$ lowv Neph \\
\hline 44 & 0.0 & $\mathrm{~T}_{\mathrm{L}} \mathrm{Neph}$ & 0.0 & $\mathrm{~T}_{\mathrm{L}} \mathrm{Neph}$ & 0.0 & $\mathrm{~T}_{\mathrm{L}} \mathrm{Neph}$ & 0.0 & $\mathrm{~T}_{\mathrm{L}} \mathrm{Neph}$ & 0.0 & $\mathrm{~T}_{\mathrm{L}}$ lowv Neph \\
\hline 45 & 0.0 & $\mathrm{~T}_{\mathrm{L}} \mathrm{Neph}$ & 0.0 & $\mathrm{~T}_{\mathrm{L}}$ Neph & 0.0 & $\mathrm{~T}_{\mathrm{L}} \mathrm{Neph}$ & 0.0 & $\mathrm{~T}_{\mathrm{L}} \mathrm{Neph}$ & 0.0 & $\mathrm{~T}_{\mathrm{L}}$ lowv Neph \\
\hline 46 & 0.0 & $\mathrm{~T}_{\mathrm{L}} \mathrm{Neph}$ & 0.0 & $\mathrm{~T}_{\mathrm{L}} \mathrm{Neph}$ & 0.0 & $\mathrm{~T}_{\mathrm{L}} \mathrm{Neph}$ & 0.0 & $\mathrm{~T}_{\mathrm{L}}$ Neph & 0.0 & $\mathrm{~T}_{\mathrm{L}}$ lowv Neph \\
\hline 47 & 0.0 & $\mathrm{~T}_{\mathrm{L}}$ lowv Neph & 0.0 & $T_{L}$ lowv Neph & 0.0 & $T_{L}$ lowv Neph & 0.0 & $T_{L}$ lowv Neph & 0.0 & $T_{L}$ lowv Neph \\
\hline 48 & 0.0 & $T_{L}$ lowv Neph & 0.0 & $\mathrm{~T}_{\mathrm{L}}$ lowv Neph & 0.0 & $T_{L}$ lowv Neph & 0.0 & $T_{L}$ lowv Neph & 0.0 & $T_{L}$ lowv Neph \\
\hline 49 & 0.0 & $\mathrm{~T}_{\mathrm{L}}$ lowv $\mathrm{SO}_{4}{ }^{2-} \mathrm{Neph}$ & 0.0 & $\mathrm{~T}_{\mathrm{L}}$ lowv $\mathrm{SO}_{4}{ }^{2-} \mathrm{Neph}$ & 0.0 & $\mathrm{~T}_{\mathrm{L}}$ lowv $\mathrm{SO}_{4}{ }^{2-} \mathrm{Neph}$ & 0.0 & $\mathrm{~T}_{\mathrm{L}}$ lowv $\mathrm{SO}_{4}{ }^{2-} \mathrm{Neph}$ & 0.0 & $\mathrm{~T}_{\mathrm{L}}$ lowv $\mathrm{SO}_{4}{ }^{2-} \mathrm{Neph}$ \\
\hline 50 & 0.0 & $\mathrm{~T}_{\mathrm{L}}$ lowv $\mathrm{SO}_{4}{ }^{2-} \mathrm{Neph}$ & 0.0 & $\mathrm{~T}_{\mathrm{L}}$ lowv $\mathrm{SO}_{4}{ }^{2-} \mathrm{Neph}$ & 0.0 & $\mathrm{~T}_{\mathrm{L}}$ lowv $\mathrm{SO}_{4}{ }^{2-} \mathrm{Neph}$ & 0.0 & $\mathrm{~T}_{\mathrm{L}}$ lowv $\mathrm{SO}_{4}{ }^{2-} \mathrm{Neph}$ & 0.0 & $\mathrm{~T}_{\mathrm{L}}$ lowv $\mathrm{SO}_{4}{ }^{2-} \mathrm{Neph}$ \\
\hline 51 & 0.0 & $\mathrm{~T}_{\mathrm{L}}$ lowv $\mathrm{SO}_{4}{ }^{2-} \mathrm{Neph}$ & 0.0 & $\mathrm{~T}_{\mathrm{L}}$ lowv $\mathrm{SO}_{4}{ }^{2-} \mathrm{Neph}$ & 0.0 & $\mathrm{~T}_{\mathrm{L}}$ lowv $\mathrm{SO}_{4}{ }^{2-} \mathrm{Neph}$ & 0.0 & $\mathrm{~T}_{\mathrm{L}}$ lowv $\mathrm{SO}_{4}{ }^{2-} \mathrm{Neph}$ & 0.0 & $\mathrm{~T}_{\mathrm{L}}$ lowv $\mathrm{SO}_{4}{ }^{2-} \mathrm{Neph}$ \\
\hline 52 & 0.0 & $\mathrm{~T}_{\mathrm{L}}$ lowv $\mathrm{SO}_{4}{ }^{2-} \mathrm{Neph}$ & 0.0 & $\mathrm{~T}_{\mathrm{L}}$ lowv $\mathrm{SO}_{4}{ }^{2-} \mathrm{Neph}$ & 0.0 & $\mathrm{~T}_{\mathrm{L}}$ lowv $\mathrm{SO}_{4}{ }^{2-} \mathrm{Neph}$ & 0.0 & $\mathrm{~T}_{\mathrm{L}}$ lowv $\mathrm{SO}_{4}{ }^{2-} \mathrm{Neph}$ & 0.0 & $\mathrm{~T}_{\mathrm{L}}$ lowv $\mathrm{SO}_{4}{ }^{2-} \mathrm{Neph}$ \\
\hline 53 & 0.0 & $\mathrm{~T}_{\mathrm{L}}$ lowv $\mathrm{SO}_{4}{ }^{2-} \mathrm{Neph}$ & 0.0 & $\mathrm{~T}_{\mathrm{L}}$ lowv $\mathrm{SO}_{4}{ }^{2-} \mathrm{Neph}$ & 0.0 & $\mathrm{~T}_{\mathrm{L}}$ lowv $\mathrm{SO}_{4}{ }^{2-} \mathrm{Neph}$ & 0.0 & $\mathrm{~T}_{\mathrm{L}}$ lowv $\mathrm{SO}_{4}{ }^{2-} \mathrm{Neph}$ & 0.0 & $\mathrm{~T}_{\mathrm{L}}$ lowv $\mathrm{SO}_{4}{ }^{2-} \mathrm{Neph}$ \\
\hline 54 & 0.0 & $\mathrm{~T}_{\mathrm{L}}$ lowv $\mathrm{SO}_{4}^{2-} \mathrm{Cr}_{2} \mathrm{O}_{3} \mathrm{Neph}$ & 0.0 & $\mathrm{~T}_{\mathrm{L}}$ lowv $\mathrm{SO}_{4}^{2-} \mathrm{Cr}_{2} \mathrm{O}_{3} \mathrm{Neph}$ & 0.0 & $\mathrm{~T}_{\mathrm{L}}$ lowv $\mathrm{SO}_{4}^{2-} \mathrm{Cr}_{2} \mathrm{O}_{3} \mathrm{Neph}$ & 0.0 & $\mathrm{~T}_{\mathrm{L}}$ lowv $\mathrm{SO}_{4}^{2-} \mathrm{Cr}_{2} \mathrm{O}_{3} \mathrm{Neph}$ & 0.0 & $\mathrm{~T}_{\mathrm{L}}$ lowv $\mathrm{SO}_{4}{ }^{2-} \mathrm{Cr}_{2} \mathrm{O}_{3} \mathrm{Neph}$ \\
\hline 55 & 0.0 & $\mathrm{~T}_{\mathrm{L}}$ lowv $\mathrm{SO}_{4}{ }^{2-} \mathrm{Cr}_{2} \mathrm{O}_{3} \mathrm{Neph}$ & 0.0 & $\mathrm{~T}_{\mathrm{L}}$ lowv $\mathrm{SO}_{4}{ }^{2-} \mathrm{Cr}_{2} \mathrm{O}_{3} \mathrm{Neph}$ & 0.0 & $\mathrm{~T}_{\mathrm{L}}$ lowv $\mathrm{SO}_{4}{ }^{2-} \mathrm{Cr}_{2} \mathrm{O}_{3} \mathrm{Neph}$ & 0.0 & $\mathrm{~T}_{\mathrm{L}}$ lowv $\mathrm{SO}_{4}{ }^{2-} \mathrm{Cr}_{2} \mathrm{O}_{3} \mathrm{Neph}$ & 0.0 & $\mathrm{~T}_{\mathrm{L}}$ lowv $\mathrm{SO}_{4}{ }^{2-} \mathrm{Cr}_{2} \mathrm{O}_{3} \mathrm{Neph}$ \\
\hline 56 & 0.0 & $\mathrm{~T}_{\mathrm{L}}$ lowv $\mathrm{SO}_{4}^{2-} \mathrm{Cr}_{2} \mathrm{O}_{3} \mathrm{Neph}$ & 0.0 & $\mathrm{~T}_{\mathrm{L}}$ lowv $\mathrm{SO}_{4}^{2-} \mathrm{Cr}_{2} \mathrm{O}_{3} \mathrm{Neph}$ & 0.0 & $\mathrm{~T}_{\mathrm{L}}$ lowv $\mathrm{SO}_{4}^{2-} \mathrm{Cr}_{2} \mathrm{O}_{3} \mathrm{Neph}$ & 0.0 & $\mathrm{~T}_{\mathrm{L}}$ lowv $\mathrm{SO}_{4}^{2-} \mathrm{Cr}_{2} \mathrm{O}_{3} \mathrm{Neph}$ & 0.0 & $\mathrm{~T}_{\mathrm{L}}$ lowv $\mathrm{SO}_{4}{ }^{2-} \mathrm{Cr}_{2} \mathrm{O}_{3} \mathrm{Neph}$ \\
\hline 57 & 0.0 & $\mathrm{~T}_{\mathrm{L}}$ lowv $\mathrm{SO}_{4}{ }^{2-} \mathrm{Cr}_{2} \mathrm{O}_{3} \mathrm{Neph}$ & 0.0 & $\mathrm{~T}_{\mathrm{L}}$ lowv $\mathrm{SO}_{4}{ }^{2-} \mathrm{Cr}_{2} \mathrm{O}_{3} \mathrm{Neph}$ & 0.0 & $\mathrm{~T}_{\mathrm{L}}$ lowv $\mathrm{SO}_{4}{ }^{2-} \mathrm{Cr}_{2} \mathrm{O}_{3} \mathrm{Neph}$ & 0.0 & $\mathrm{~T}_{\mathrm{L}}$ lowv $\mathrm{SO}_{4}{ }^{2-} \mathrm{Cr}_{2} \mathrm{O}_{3} \mathrm{Neph}$ & 0.0 & $\mathrm{~T}_{\mathrm{L}}$ lowv $\mathrm{SO}_{4}{ }^{2-} \mathrm{Cr}_{2} \mathrm{O}_{3} \mathrm{Neph}$ \\
\hline 58 & 0.0 & $\mathrm{~T}_{\mathrm{L}}$ lowv $\mathrm{SO}_{4}^{2-} \mathrm{Cr}_{2} \mathrm{O}_{3} \mathrm{Neph}$ & 0.0 & $\mathrm{~T}_{\mathrm{L}}$ lowv $\mathrm{SO}_{4}^{2-} \mathrm{Cr}_{2} \mathrm{O}_{3} \mathrm{Neph}$ & 0.0 & $\mathrm{~T}_{\mathrm{L}}$ lowv $\mathrm{SO}_{4}^{2-} \mathrm{Cr}_{2} \mathrm{O}_{3} \mathrm{Neph}$ & 0.0 & $\mathrm{~T}_{\mathrm{L}}$ lowv $\mathrm{SO}_{4}{ }^{2-} \mathrm{Cr}_{2} \mathrm{O}_{3} \mathrm{Neph}$ & 0.0 & $\mathrm{~T}_{\mathrm{L}}$ lowv $\mathrm{SO}_{4}{ }^{2-} \mathrm{Cr}_{2} \mathrm{O}_{3} \mathrm{Neph}$ \\
\hline 59 & 0.0 & $\mathrm{~T}_{\mathrm{L}}$ lowv $\mathrm{SO}_{4}{ }^{2-} \mathrm{Cr}_{2} \mathrm{O}_{3} \mathrm{Neph}$ & 0.0 & $\mathrm{~T}_{\mathrm{L}}$ lowv $\mathrm{SO}_{4}{ }^{2-} \mathrm{Cr}_{2} \mathrm{O}_{3} \mathrm{Neph}$ & 0.0 & $\mathrm{~T}_{\mathrm{L}}$ lowv $\mathrm{SO}_{4}{ }^{2-} \mathrm{Cr}_{2} \mathrm{O}_{3} \mathrm{Neph}$ & 0.0 & $\mathrm{~T}_{\mathrm{L}}$ lowv $\mathrm{SO}_{4}^{2-} \mathrm{Cr}_{2} \mathrm{O}_{3} \mathrm{Neph}$ & 0.0 & $\mathrm{~T}_{\mathrm{L}}$ lowv $\mathrm{SO}_{4}{ }^{2-} \mathrm{Cr}_{2} \mathrm{O}_{3} \mathrm{Neph}$ \\
\hline 60 & 0.0 & $\mathrm{~T}_{\mathrm{L}}$ lowv $\mathrm{SO}_{4}{ }^{2-} \mathrm{Cr}_{2} \mathrm{O}_{3} \mathrm{Neph}$ & 0.0 & $\mathrm{~T}_{\mathrm{L}}$ lowv $\mathrm{SO}_{4}{ }^{2-} \mathrm{Cr}_{2} \mathrm{O}_{3} \mathrm{Neph}$ & 0.0 & $\mathrm{~T}_{\mathrm{L}}$ lowv $\mathrm{SO}_{4}{ }^{2-} \mathrm{Cr}_{2} \mathrm{O}_{3} \mathrm{Neph}$ & 0.0 & $\mathrm{~T}_{\mathrm{L}}$ lowv $\mathrm{SO}_{4}{ }^{2-} \mathrm{Cr}_{2} \mathrm{O}_{3} \mathrm{Neph}$ & 0.0 & $\mathrm{~T}_{\mathrm{L}}$ lowv $\mathrm{SO}_{4}{ }^{2-} \mathrm{Cr}_{2} \mathrm{O}_{3} \mathrm{Neph}$ \\
\hline
\end{tabular}


Table A4. Results of the Variation Stage assessment for sludge Case $C$ with the five candidate frits.

\begin{tabular}{|c|c|c|c|c|c|c|c|c|c|c|}
\hline \multirow[b]{2}{*}{ WL } & \multicolumn{2}{|r|}{ Frit 530} & \multicolumn{2}{|r|}{ Frit 531} & \multicolumn{2}{|r|}{ Frit 532} & \multicolumn{2}{|r|}{ Frit 533} & \multicolumn{2}{|r|}{ Frit 535} \\
\hline & $\begin{array}{l}\text { Percent } \\
\text { of EVs }\end{array}$ & Limiting Constraint(s) & $\begin{array}{l}\text { Percent } \\
\text { of EVs }\end{array}$ & Limiting Constraint(s) & $\begin{array}{l}\text { Percent } \\
\text { of EVs }\end{array}$ & Limiting Constraint(s) & $\begin{array}{c}\text { Percent } \\
\text { of EVs }\end{array}$ & Limiting Constraint(s) & $\begin{array}{l}\text { Percent } \\
\text { of EVs }\end{array}$ & Limiting Constraint(s) \\
\hline 25 & 100.0 & & 90.7 & Homg & 90.7 & & 0.0 & Homg hFrit & 0.0 & Homg hFrit \\
\hline 26 & 100.0 & & 99.4 & Homg & 99.4 & & 21.4 & Homg & 21.4 & Homg \\
\hline 27 & 100.0 & & 100.0 & & 100.0 & & 34.0 & Homg & 34.0 & Homg \\
\hline 28 & 100.0 & & 100.0 & & 100.0 & & 85.6 & Homg & 85.6 & Homg \\
\hline 29 & 100.0 & & 100.0 & & 100.0 & & 97.1 & Homg & 97.1 & Homg \\
\hline 30 & 100.0 & & 100.0 & & 100.0 & & 100.0 & & 100.0 & \\
\hline 31 & 100.0 & & 100.0 & & 100.0 & & 100.0 & & 100.0 & \\
\hline 32 & 100.0 & & 100.0 & & 100.0 & & 100.0 & & 100.0 & \\
\hline 33 & 100.0 & & 100.0 & & 100.0 & & 100.0 & & 100.0 & \\
\hline 34 & 100.0 & & 100.0 & & 100.0 & & 100.0 & & 100.0 & \\
\hline 35 & 100.0 & & 100.0 & & 98.6 & $\mathrm{~T}_{\mathrm{L}}$ & 98.9 & $\mathrm{~T}_{\mathrm{L}}$ & 100.0 & \\
\hline 36 & 99.4 & $T_{L}$ & 99.6 & $\mathrm{~T}_{\mathrm{L}}$ & 91.8 & $\mathrm{~T}_{\mathrm{L}}$ & 92.2 & $\mathrm{~T}_{\mathrm{L}}$ & 100.0 & \\
\hline 37 & 93.6 & $\mathrm{~T}_{\mathrm{L}}$ & 94.0 & $\mathrm{~T}_{\mathrm{L}}$ & 79.9 & $\mathrm{~T}_{\mathrm{L}}$ & 80.4 & $\mathrm{~T}_{\mathrm{L}}$ & 99.4 & $\mathrm{~T}_{\mathrm{L}}$ \\
\hline 38 & 84.1 & $\mathrm{~T}_{\mathrm{L}}$ & 84.8 & $\mathrm{~T}_{\mathrm{L}}$ & 71.1 & $\mathrm{~T}_{\mathrm{L}}$ & 71.5 & $\mathrm{~T}_{\mathrm{L}}$ & 93.6 & $T_{L}$ \\
\hline 39 & 73.9 & $\mathrm{~T}_{\mathrm{L}}$ & 74.4 & $\mathrm{~T}_{\mathrm{L}}$ & 59.6 & $T_{L}$ & 59.8 & $\mathrm{~T}_{\mathrm{L}}$ & 72.0 & $\mathrm{~T}_{\mathrm{L}}$ lowV \\
\hline 40 & 63.0 & $\mathrm{~T}_{\mathrm{L}}$ & 63.8 & $\mathrm{~T}_{\mathrm{L}}$ & 49.2 & $\mathrm{~T}_{\mathrm{L}}$ & 30.2 & $\mathrm{~T}_{\mathrm{L}} \mathrm{Neph}$ & 25.7 & $T_{L}$ lowv Neph \\
\hline 41 & 34.8 & $\mathrm{~T}_{\mathrm{L}} \mathrm{Neph}$ & 45.1 & $\mathrm{~T}_{\mathrm{L}} \mathrm{Neph}$ & 16.0 & $\mathrm{~T}_{\mathrm{L}} \mathrm{Neph}$ & 12.9 & $\mathrm{~T}_{\mathrm{L}} \mathrm{Neph}$ & 2.5 & $\mathrm{~T}_{\mathrm{L}}$ lowv Neph \\
\hline 42 & 15.0 & $\mathrm{~T}_{\mathrm{L}}$ Neph & 18.5 & $\mathrm{~T}_{\mathrm{L}} \mathrm{Neph}$ & 4.7 & $\mathrm{~T}_{\mathrm{L}} \mathrm{Neph}$ & 0.1 & $\mathrm{~T}_{\mathrm{L}} \mathrm{Neph}$ & 0.0 & $\mathrm{~T}_{\mathrm{L}}$ lowv Neph \\
\hline 43 & 0.3 & $\mathrm{~T}_{\mathrm{L}} \mathrm{Neph}$ & 5.2 & $\mathrm{~T}_{\mathrm{L}} \mathrm{Neph}$ & 0.0 & $\mathrm{~T}_{\mathrm{L}}$ Neph & 0.0 & $\mathrm{~T}_{\mathrm{L}}$ Neph & 0.0 & $\mathrm{~T}_{\mathrm{L}}$ lowv Neph \\
\hline 44 & 0.0 & $\mathrm{~T}_{\mathrm{L}}$ lowv Neph & 0.0 & $\mathrm{~T}_{\mathrm{L}}$ Neph & 0.0 & $\mathrm{~T}_{\mathrm{L}}$ lowv Neph & 0.0 & $\mathrm{~T}_{\mathrm{L}}$ lowv Neph & 0.0 & $\mathrm{~T}_{\mathrm{L}}$ lowv Neph \\
\hline 45 & 0.0 & $\mathrm{~T}_{\mathrm{L}}$ lowv Neph & 0.0 & $\mathrm{~T}_{\mathrm{L}}$ lowv Neph & 0.0 & $\mathrm{~T}_{\mathrm{L}}$ lowv Neph & 0.0 & $\mathrm{~T}_{\mathrm{L}}$ lowv Neph & 0.0 & $\mathrm{~T}_{\mathrm{L}}$ lowv Neph \\
\hline 46 & 0.0 & $\mathrm{~T}_{\mathrm{L}}$ lowv Neph & 0.0 & $\mathrm{~T}_{\mathrm{L}}$ lowv Neph & 0.0 & $\mathrm{~T}_{\mathrm{L}}$ lowv Neph & 0.0 & $\mathrm{~T}_{\mathrm{L}}$ lowv Neph & 0.0 & $\mathrm{~T}_{\mathrm{L}}$ lowv Neph \\
\hline 47 & 0.0 & $\mathrm{~T}_{\mathrm{L}}$ lowv $\mathrm{SO}_{4}{ }^{2-} \mathrm{Neph}$ & 0.0 & $\mathrm{~T}_{\mathrm{L}}$ lowv $\mathrm{SO}_{4}{ }^{2-} \mathrm{Neph}$ & 0.0 & $\mathrm{~T}_{\mathrm{L}}$ lowv $\mathrm{SO}_{4}^{2-} \mathrm{Neph}$ & 0.0 & $\mathrm{~T}_{\mathrm{L}}$ lowv $\mathrm{SO}_{4}^{2-} \mathrm{Neph}$ & 0.0 & $\mathrm{~T}_{\mathrm{L}}$ lowv $\mathrm{SO}_{4}{ }^{2-} \mathrm{Neph}$ \\
\hline 48 & 0.0 & $\mathrm{~T}_{\mathrm{L}}$ lowv $\mathrm{SO}_{4}{ }^{2-} \mathrm{Neph}$ & 0.0 & $\mathrm{~T}_{\mathrm{L}}$ lowv $\mathrm{SO}_{4}{ }^{2-} \mathrm{Neph}$ & 0.0 & $\mathrm{~T}_{\mathrm{L}}$ lowv $\mathrm{SO}_{4}{ }^{2-} \mathrm{Neph}$ & 0.0 & $\mathrm{~T}_{\mathrm{L}}$ lowv $\mathrm{SO}_{4}{ }^{2-} \mathrm{Neph}$ & 0.0 & $\mathrm{~T}_{\mathrm{L}}$ lowv $\mathrm{SO}_{4}{ }^{2-} \mathrm{Neph}$ \\
\hline 49 & 0.0 & $\mathrm{~T}_{\mathrm{L}}$ lowv $\mathrm{SO}_{4}{ }^{2-} \mathrm{Cr}_{2} \mathrm{O}_{3} \mathrm{Neph}$ & 0.0 & $\mathrm{~T}_{\mathrm{L}}$ lowv $\mathrm{SO}_{4}{ }^{2-} \mathrm{Cr}_{2} \mathrm{O}_{3} \mathrm{Neph}$ & 0.0 & $\mathrm{~T}_{\mathrm{L}}$ lowv $\mathrm{SO}_{4}{ }^{2-} \mathrm{Cr}_{2} \mathrm{O}_{3} \mathrm{Neph}$ & 0.0 & $\mathrm{~T}_{\mathrm{L}}$ lowv $\mathrm{SO}_{4}{ }^{2-} \mathrm{Cr}_{2} \mathrm{O}_{3} \mathrm{Neph}$ & 0.0 & $\mathrm{~T}_{\mathrm{L}}$ lowv $\mathrm{SO}_{4}{ }^{2-} \mathrm{Cr}_{2} \mathrm{O}_{3} \mathrm{Neph}$ \\
\hline 50 & 0.0 & $\mathrm{~T}_{\mathrm{L}}$ lowv $\mathrm{SO}_{4}{ }^{2-} \mathrm{Cr}_{2} \mathrm{O}_{3} \mathrm{Neph}$ & 0.0 & $\mathrm{~T}_{\mathrm{L}}$ lowv $\mathrm{SO}_{4}^{2-} \mathrm{Cr}_{2} \mathrm{O}_{3} \mathrm{Neph}$ & 0.0 & $\mathrm{~T}_{\mathrm{L}}$ lowv $\mathrm{SO}_{4}^{2-} \mathrm{Cr}_{2} \mathrm{O}_{3} \mathrm{Neph}$ & 0.0 & $\mathrm{~T}_{\mathrm{L}}$ lowv $\mathrm{SO}_{4}{ }_{4}^{2-} \mathrm{Cr}_{2} \mathrm{O}_{3} \mathrm{Neph}$ & 0.0 & $\mathrm{~T}_{\mathrm{L}}$ lowv $\mathrm{SO}_{4}{ }^{2-} \mathrm{Cr}_{2} \mathrm{O}_{3} \mathrm{Neph}$ \\
\hline 51 & 0.0 & $\mathrm{~T}_{\mathrm{L}}$ lowv $\mathrm{SO}_{4}{ }^{2-} \mathrm{Cr}_{2} \mathrm{O}_{3} \mathrm{Neph}$ & 0.0 & $\mathrm{~T}_{\mathrm{L}}$ lowv $\mathrm{SO}_{4}{ }^{2-} \mathrm{Cr}_{2} \mathrm{O}_{3} \mathrm{Neph}$ & 0.0 & $\mathrm{~T}_{\mathrm{L}}$ lowv $\mathrm{SO}_{4}{ }^{2-} \mathrm{Cr}_{2} \mathrm{O}_{3} \mathrm{Neph}$ & 0.0 & $\mathrm{~T}_{\mathrm{L}}$ lowv $\mathrm{SO}_{4}{ }^{2-} \mathrm{Cr}_{2} \mathrm{O}_{3} \mathrm{Neph}$ & 0.0 & $\mathrm{~T}_{\mathrm{L}}$ lowv $\mathrm{SO}_{4}{ }^{2-} \mathrm{Cr}_{2} \mathrm{O}_{3} \mathrm{Neph}$ \\
\hline 52 & 0.0 & $\mathrm{~T}_{\mathrm{L}}$ lowv $\mathrm{SO}_{4}{ }^{2-} \mathrm{Cr}_{2} \mathrm{O}_{3} \mathrm{Neph}$ & 0.0 & $\mathrm{~T}_{\mathrm{L}}$ lowv $\mathrm{SO}_{4}{ }^{2-} \mathrm{Cr}_{2} \mathrm{O}_{3} \mathrm{Neph}$ & 0.0 & $\mathrm{~T}_{\mathrm{L}}$ lowv $\mathrm{SO}_{4}^{2-} \mathrm{Cr}_{2} \mathrm{O}_{3} \mathrm{Neph}$ & 0.0 & $\mathrm{~T}_{\mathrm{L}}$ lowv $\mathrm{SO}_{4}{ }^{2-} \mathrm{Cr}_{2} \mathrm{O}_{3} \mathrm{Neph}$ & 0.0 & $\mathrm{~T}_{\mathrm{L}}$ lowv $\mathrm{SO}_{4}{ }^{2-} \mathrm{Cr}_{2} \mathrm{O}_{3} \mathrm{Neph}$ \\
\hline 53 & 0.0 & $\mathrm{~T}_{\mathrm{L}}$ lowv $\mathrm{SO}_{4}{ }^{2-} \mathrm{Cr}_{2} \mathrm{O}_{3} \mathrm{Neph}$ & 0.0 & $\mathrm{~T}_{\mathrm{L}}$ lowv $\mathrm{SO}_{4}{ }^{2-} \mathrm{Cr}_{2} \mathrm{O}_{3} \mathrm{Neph}$ & 0.0 & $\mathrm{~T}_{\mathrm{L}}$ lowv $\mathrm{SO}_{4}{ }^{2-} \mathrm{Cr}_{2} \mathrm{O}_{3} \mathrm{Neph}$ & 0.0 & $\mathrm{~T}_{\mathrm{L}}$ lowv $\mathrm{SO}_{4}{ }^{2-} \mathrm{Cr}_{2} \mathrm{O}_{3} \mathrm{Neph}$ & 0.0 & $\mathrm{~T}_{\mathrm{L}}$ lowv $\mathrm{SO}_{4}{ }^{2-} \mathrm{Cr}_{2} \mathrm{O}_{3} \mathrm{Neph}$ \\
\hline 54 & 0.0 & $\mathrm{~T}_{\mathrm{L}}$ lowv $\mathrm{SO}_{4}{ }^{2-} \mathrm{Cr}_{2} \mathrm{O}_{3} \mathrm{Neph}$ & 0.0 & $\mathrm{~T}_{\mathrm{L}}$ lowv $\mathrm{SO}_{4}{ }^{2-} \mathrm{Cr}_{2} \mathrm{O}_{3} \mathrm{Neph}$ & 0.0 & $\mathrm{~T}_{\mathrm{L}}$ lowv $\mathrm{SO}_{4}{ }^{2-} \mathrm{Cr}_{2} \mathrm{O}_{3} \mathrm{Neph}$ & 0.0 & $\mathrm{~T}_{\mathrm{L}}$ lowv $\mathrm{SO}_{4}{ }^{2-} \mathrm{Cr}_{2} \mathrm{O}_{3} \mathrm{Neph}$ & 0.0 & $\mathrm{~T}_{\mathrm{L}}$ lowv $\mathrm{SO}_{4}{ }^{2-} \mathrm{Cr}_{2} \mathrm{O}_{3} \mathrm{Neph}$ \\
\hline 55 & 0.0 & $\mathrm{~T}_{\mathrm{L}}$ lowv $\mathrm{SO}_{4}{ }^{2-} \mathrm{Cr}_{2} \mathrm{O}_{3} \mathrm{Neph}$ & 0.0 & $\mathrm{~T}_{\mathrm{L}}$ lowv $\mathrm{SO}_{4}{ }^{2-} \mathrm{Cr}_{2} \mathrm{O}_{3} \mathrm{Neph}$ & 0.0 & $\mathrm{~T}_{\mathrm{L}}$ lowv $\mathrm{SO}_{4}{ }^{2-} \mathrm{Cr}_{2} \mathrm{O}_{3} \mathrm{Neph}$ & 0.0 & $\mathrm{~T}_{\mathrm{L}}$ lowv $\mathrm{SO}_{4}{ }^{2-} \mathrm{Cr}_{2} \mathrm{O}_{3} \mathrm{Neph}$ & 0.0 & $\mathrm{~T}_{\mathrm{L}}$ lowv $\mathrm{SO}_{4}{ }^{2-} \mathrm{Cr}_{2} \mathrm{O}_{3} \mathrm{Neph}$ \\
\hline 56 & 0.0 & $\mathrm{~T}_{\mathrm{L}}$ lowv $\mathrm{SO}_{4}{ }^{2-} \mathrm{Cr}_{2} \mathrm{O}_{3} \mathrm{Neph}$ & 0.0 & $\mathrm{~T}_{\mathrm{L}}$ lowv $\mathrm{SO}_{4}{ }^{2-} \mathrm{Cr}_{2} \mathrm{O}_{3} \mathrm{Neph}$ & 0.0 & $\mathrm{~T}_{\mathrm{L}}$ lowv $\mathrm{SO}_{4}^{2-} \mathrm{Cr}_{2} \mathrm{O}_{3} \mathrm{Neph}$ & 0.0 & $\mathrm{~T}_{\mathrm{L}}$ lowv $\mathrm{SO}_{4}{ }^{2-} \mathrm{Cr}_{2} \mathrm{O}_{3} \mathrm{Neph}$ & 0.0 & $\mathrm{~T}_{\mathrm{L}}$ lowv $\mathrm{SO}_{4}{ }^{2-} \mathrm{Cr}_{2} \mathrm{O}_{3} \mathrm{Neph}$ \\
\hline 57 & 0.0 & $\mathrm{~T}_{\mathrm{L}}$ lowv $\mathrm{SO}_{4}{ }^{2-} \mathrm{Cr}_{2} \mathrm{O}_{3} \mathrm{Neph}$ & 0.0 & $\mathrm{~T}_{\mathrm{L}}$ lowv $\mathrm{SO}_{4}{ }^{2-} \mathrm{Cr}_{2} \mathrm{O}_{3} \mathrm{Neph}$ & 0.0 & $\mathrm{~T}_{\mathrm{L}}$ lowv $\mathrm{SO}_{4}{ }^{2-} \mathrm{Cr}_{2} \mathrm{O}_{3} \mathrm{Neph}$ & 0.0 & $\mathrm{~T}_{\mathrm{L}}$ lowv $\mathrm{SO}_{4}{ }^{2-} \mathrm{Cr}_{2} \mathrm{O}_{3} \mathrm{Neph}$ & 0.0 & $\mathrm{~T}_{\mathrm{L}}$ lowv $\mathrm{SO}_{4}{ }^{2-} \mathrm{Cr}_{2} \mathrm{O}_{3} \mathrm{Neph}$ \\
\hline 58 & 0.0 & $\mathrm{~T}_{\mathrm{L}}$ lowv $\mathrm{SO}_{4}{ }^{2-} \mathrm{Cr}_{2} \mathrm{O}_{3} \mathrm{Neph}$ & 0.0 & $\mathrm{~T}_{\mathrm{L}}$ lowv $\mathrm{SO}_{4}{ }^{2-} \mathrm{Cr}_{2} \mathrm{O}_{3} \mathrm{Neph}$ & 0.0 & $\mathrm{~T}_{\mathrm{L}}$ lowv $\mathrm{SO}_{4}{ }^{2-} \mathrm{Cr}_{2} \mathrm{O}_{3} \mathrm{Neph}$ & 0.0 & $\mathrm{~T}_{\mathrm{L}}$ lowv $\mathrm{SO}_{4}{ }^{2-} \mathrm{Cr}_{2} \mathrm{O}_{3} \mathrm{Neph}$ & 0.0 & $\mathrm{~T}_{\mathrm{L}}$ lowv $\mathrm{SO}_{4}{ }^{2-} \mathrm{Cr}_{2} \mathrm{O}_{3} \mathrm{Neph}$ \\
\hline 59 & 0.0 & $\mathrm{~T}_{\mathrm{L}}$ lowv $\mathrm{SO}_{4}{ }^{2-} \mathrm{Cr}_{2} \mathrm{O}_{3} \mathrm{Neph}$ & 0.0 & $\mathrm{~T}_{\mathrm{L}}$ lowv $\mathrm{SO}_{4}{ }^{2-} \mathrm{Cr}_{2} \mathrm{O}_{3} \mathrm{Neph}$ & 0.0 & $\mathrm{~T}_{\mathrm{L}}$ lowv $\mathrm{SO}_{4}{ }^{2-} \mathrm{Cr}_{2} \mathrm{O}_{3} \mathrm{Neph}$ & 0.0 & $\mathrm{~T}_{\mathrm{L}}$ lowv $\mathrm{SO}_{4}{ }^{2-} \mathrm{Cr}_{2} \mathrm{O}_{3} \mathrm{Neph}$ & 0.0 & $\mathrm{~T}_{\mathrm{L}}$ lowv $\mathrm{SO}_{4}{ }^{2-} \mathrm{Cr}_{2} \mathrm{O}_{3} \mathrm{Neph}$ \\
\hline 60 & 0.0 & $\mathrm{~T}_{\mathrm{L}}$ lowv $\mathrm{SO}_{4}{ }^{2-} \mathrm{Cr}_{2} \mathrm{O}_{3} \mathrm{Neph}$ & 0.0 & $\mathrm{~T}_{\mathrm{L}}$ lowv $\mathrm{SO}_{4}{ }^{2-} \mathrm{Cr}_{2} \mathrm{O}_{3} \mathrm{Neph}$ & 0.0 & $\mathrm{~T}_{\mathrm{L}}$ lowv $\mathrm{SO}_{4}{ }^{2-} \mathrm{Cr}_{2} \mathrm{O}_{3} \mathrm{Neph}$ & 0.0 & $\mathrm{~T}_{\mathrm{L}}$ lowv $\mathrm{SO}_{4}{ }^{2-} \mathrm{Cr}_{2} \mathrm{O}_{3} \mathrm{Neph}$ & 0.0 & $\mathrm{~T}_{\mathrm{L}}$ lowv $\mathrm{SO}_{4}{ }^{2-} \mathrm{Cr}_{2} \mathrm{O}_{3} \mathrm{Neph}$ \\
\hline
\end{tabular}


WSRC-STI-2008-00006

Revision 0

Table A5. Complete Nominal Stage results for Sludge Case F with Frits 530, 531, and 532.

\begin{tabular}{|c|c|c|c|}
\hline $\mathbf{W}_{\mathrm{L}}$ & Frit 530 & Frit 531 & Frit 532 \\
\hline \multicolumn{4}{|l|}{25} \\
\hline \multicolumn{4}{|l|}{26} \\
\hline \multicolumn{4}{|l|}{27} \\
\hline \multicolumn{4}{|l|}{28} \\
\hline \multicolumn{4}{|l|}{29} \\
\hline \multicolumn{4}{|l|}{30} \\
\hline \multicolumn{4}{|l|}{31} \\
\hline \multicolumn{4}{|l|}{32} \\
\hline \multicolumn{4}{|l|}{33} \\
\hline \multicolumn{4}{|l|}{34} \\
\hline \multicolumn{4}{|l|}{35} \\
\hline \multicolumn{4}{|l|}{36} \\
\hline \multicolumn{4}{|l|}{37} \\
\hline \multicolumn{4}{|l|}{38} \\
\hline \multicolumn{4}{|l|}{39} \\
\hline \multicolumn{4}{|l|}{40} \\
\hline 41 & & & $\mathrm{~T}_{\mathrm{L}} \mathrm{Neph}$ \\
\hline 42 & $\mathrm{~T}_{\mathrm{L}} \mathrm{Neph}$ & $\mathrm{T}_{\mathrm{L}} \mathrm{Neph}$ & $\mathrm{T}_{\mathrm{L}} \mathrm{Neph}$ \\
\hline 43 & $\mathrm{~T}_{\mathrm{L}} \mathrm{Neph}$ & $\mathrm{T}_{\mathrm{L}} \mathrm{Neph}$ & $\mathrm{T}_{\mathrm{L}} \mathrm{Neph}$ \\
\hline 44 & $\mathrm{~T}_{\mathrm{L}} \mathrm{Neph}$ & $\mathrm{T}_{\mathrm{L}} \mathrm{Neph}$ & $\mathrm{T}_{\mathrm{L}} \mathrm{Neph}$ \\
\hline 45 & $\mathrm{~T}_{\mathrm{L}} \mathrm{Neph}$ & $\mathrm{T}_{\mathrm{L}} \mathrm{Neph}$ & $\mathrm{T}_{\mathrm{L}} \mathrm{Neph}$ \\
\hline 46 & $\mathrm{~T}_{\mathrm{L}} \mathrm{Neph}$ & $\mathrm{T}_{\mathrm{L}} \mathrm{Neph}$ & $\mathrm{T}_{\mathrm{L}} \mathrm{Neph}$ \\
\hline 47 & $\mathrm{~T}_{\mathrm{L}} \mathrm{Neph}$ & $\mathrm{T}_{\mathrm{L}} \mathrm{Neph}$ & $\mathrm{T}_{\mathrm{L}} \mathrm{Neph}$ \\
\hline 48 & $\mathrm{~T}_{\mathrm{L}} \mathrm{Neph}$ & $\mathrm{T}_{\mathrm{L}} \mathrm{Neph}$ & $\mathrm{T}_{\mathrm{L}} \mathrm{Neph}$ \\
\hline 49 & $\mathrm{~T}_{\mathrm{L}} \mathrm{Neph}$ & $\mathrm{T}_{\mathrm{L}} \mathrm{Neph}$ & $\mathrm{T}_{\mathrm{L}} \mathrm{Neph}$ \\
\hline 50 & $\mathrm{~T}_{\mathrm{L}} \mathrm{Neph}$ & $\mathrm{T}_{\mathrm{L}} \mathrm{Neph}$ & $\mathrm{T}_{\mathrm{L}} \mathrm{Neph}$ \\
\hline 51 & $\mathrm{~T}_{\mathrm{L}} \mathrm{Neph}$ & $\mathrm{T}_{\mathrm{L}} \mathrm{Neph}$ & $\mathrm{T}_{\mathrm{L}}$ lowv Neph \\
\hline 52 & $\mathrm{~T}_{\mathrm{L}}$ lowv Neph & $\mathrm{T}_{\mathrm{L}}$ lowv Neph & $\mathrm{T}_{\mathrm{L}}$ lowv Neph \\
\hline 53 & $\mathrm{~T}_{\mathrm{L}}$ lowv Neph & $\mathrm{T}_{\mathrm{L}}$ lowv Neph & $\mathrm{T}_{\mathrm{L}}$ lowv Neph \\
\hline 54 & $\mathrm{~T}_{\mathrm{L}}$ lowv $\mathrm{SO}_{4}{ }^{2-} \mathrm{Neph}$ & $\mathrm{T}_{\mathrm{L}}$ lowv $\mathrm{SO}_{4}^{2-} \mathrm{Neph}$ & $\mathrm{T}_{\mathrm{L}}$ lowv $\mathrm{SO}_{4}{ }^{2-} \mathrm{Neph}$ \\
\hline 55 & $\mathrm{~T}_{\mathrm{L}}$ lowv $\mathrm{SO}_{4}{ }^{2-} \mathrm{Neph}$ & $\mathrm{T}_{\mathrm{L}}$ lowv $\mathrm{SO}_{4}{ }^{2-} \mathrm{Neph}$ & $\mathrm{T}_{\mathrm{L}}$ lowv $\mathrm{SO}_{4}{ }^{2-} \mathrm{Neph}$ \\
\hline 56 & $\mathrm{~T}_{\mathrm{L}}$ lowv $\mathrm{SO}_{4}{ }^{2-} \mathrm{Neph}$ & $\mathrm{T}_{\mathrm{L}}$ lowv $\mathrm{SO}_{4}{ }^{2-} \mathrm{Neph}$ & $\mathrm{T}_{\mathrm{L}}$ lowv $\mathrm{SO}_{4}{ }^{2-} \mathrm{Neph}$ \\
\hline 57 & $\mathrm{~T}_{\mathrm{L}}$ lowv $\mathrm{SO}_{4}{ }^{2-} \mathrm{Neph}$ & $\mathrm{T}_{\mathrm{L}}$ lowv $\mathrm{SO}_{4}{ }^{2-} \mathrm{Neph}$ & $\mathrm{T}_{\mathrm{L}}$ lowv $\mathrm{SO}_{4}{ }^{2-} \mathrm{Neph}$ \\
\hline 58 & $\mathrm{~T}_{\mathrm{L}}$ lowv $\mathrm{SO}_{4}{ }^{2-} \mathrm{Neph}$ & $\mathrm{T}_{\mathrm{L}}$ lowv $\mathrm{SO}_{4}{ }^{2-} \mathrm{Neph}$ & $\mathrm{T}_{\mathrm{L}}$ lowv $\mathrm{SO}_{4}{ }^{2-} \mathrm{Neph}$ \\
\hline 59 & $\mathrm{~T}_{\mathrm{L}}$ lowv $\mathrm{SO}_{4}^{2-} \mathrm{Neph}$ & $\mathrm{T}_{\mathrm{L}}$ lowv $\mathrm{SO}_{4}{ }^{2-} \mathrm{Neph}$ & $\mathrm{T}_{\mathrm{L}}$ lowv $\mathrm{SO}_{4}{ }^{2-} \mathrm{Neph}$ \\
\hline 60 & $\mathrm{~T}_{\mathrm{L}}$ lowv $\mathrm{SO}_{4}{ }^{2-} \mathrm{Cr}_{2} \mathrm{O}_{3} \mathrm{Neph}$ & $\mathrm{T}_{\mathrm{L}}$ lowv $\mathrm{SO}_{4}{ }^{2-} \mathrm{Cr}_{2} \mathrm{O}_{3} \mathrm{Neph}$ & $\mathrm{T}_{\mathrm{L}}$ lowv $\mathrm{SO}_{4}{ }^{2-} \mathrm{Cr}_{2} \mathrm{O}_{3} \mathrm{Neph}$ \\
\hline
\end{tabular}




\section{Distribution:}

C.J. Bannochie, 773-42A

R.T. McNew, 704-27S

A.B. Barnes, 999-W

D.H. Miller, 999-W

D.R. Best, 786-1A

T.A. Nance, 773-42A

D.A. Crowley, 999-W

J.D. Newell, 999-W

B.A. Davis, 704-27S

J.E. Occhipinti, 704-S

T.B. Edwards, 999-W

D.K. Peeler, 999-W

K.M. Fox, 999-W

F.C. Raszewski, 999-W

B.J. Giddings, 786-5A

I.A. Reamer, 999-1W

J.M. Gillam, 766-H

J.C. Griffin, 773-A

H.B. Shah, 766-H

B.A. Hamm, 766-H

M.E. Smith, 999-W

C.C. Herman, 999-W

M.E. Stone, 999-W

J.F. Iaukea, 704-30S

J. Stuberfield, 766-H

C. M. Jantzen, 773-A

R.J. Workman, 999-1W

T.M. Jones, 999-W

A.L. Youchak, 999-W 